The research program of the Center for Economic Studies (CES) produces a wide range of theoretical and empirical economic analyses that serve to improve the statistical programs of the U.S. Bureau of the Census. Many of these analyses take the form of CES research papers. The papers are intended to make the results of CES research available to economists and other interested parties in order to encourage discussion and obtain suggestions for revision before publication. The papers are unofficial and have not undergone the review accorded official Census Bureau publications. The opinions and conclusions expressed in the papers are those of the authors and do not necessarily represent those of the U.S. Bureau of the Census. Republication in whole or part must be cleared with the authors.

\title{
CHOICES OF METROPOLITAN DESTINATIONS BY THE 1995-2000 NEW IMMIGRANTS BORN IN MEXICO AND INDIA:
}

\author{
CHARACTERIZATION AND MULTIVARIATE EXPLANATION
}

by

\author{
Kao-Lee Liaw * \\ McMaster University
}

and

\author{
William H. Frey* \\ University of Michigan
}

CES 08-27 September, 2008

All papers are screened to ensure that they do not disclose confidential information. Persons who wish to obtain a copy of the paper, submit comments about the paper, or obtain general information about the series should contact Sang V. Nguyen, Editor, Discussion Papers, Center for Economic Studies, Bureau of the Census, 4600 Silver Hill Road, 2K132F, Washington, DC 20233, (301-763-1882) or INTERNET address sang.v.nguyen@census.gov. 


\begin{abstract}
Using the confidential long-form records of the 2000 population census, we study the choices of metropolitan destinations made by the Mexican-born and Indian-born immigrants who arrived in the United States in 1995-2000. Based on the application of a multinomial logit model to the data of each of these two ethnic groups, our main findings are as follows. The destination choice behaviors of both ethnic groups were in general consistent with the major theories of migration. Both groups were subject to (1) the attraction of co-ethnic communities and (2) the positive effects of wage level and total employment growth. With respect to the job increases in different wage deciles, both ethnic groups share the pattern that the less educated were subject to the pull of increase in low-wage jobs, whereas the better educated were subject to the pull of increase in high-wage jobs. With respect to the possibility of competitions against other foreignborn ethnics, both ethnic groups were found to be more prone to selecting destinations where their co-ethnics represented a relatively high proportion of the foreign-born population.

The main differences in destination choice behaviors between the two ethnic groups resulted partly from the fact that the relative explanatory powers of our chosen explanatory factors differed substantially between the two ethnic groups. The Mexican-born were more subject to the attractions of (1) larger co-ethnic communities, (2) greater overall employment growth, (3) more job increases in low wage deciles, and (4) greater share of the foreign-born population by co-ethnics. In contrast, the Indian-born were more attracted by (1) higher wage level, and (2) more job increases in high wage deciles.
\end{abstract}

* We are grateful to Cathy Sun of the University of Michigan for programming assistance and to the supports of NIH/NICHD (grant number: R01-HD045421-01A1), NSF (grant number: SES-0319082), and the Brookings Institution Metropolitan Policy Program. We also thank the Census Bureau for granting us the privilege to access the long-form records of the 1990 and 2000 population censuses. The research in this paper was conducted while the authors were Special Sworn Status researchers of the U.S. Census Bureau at the Michigan Census Research Data Center. Research results and conclusions expressed are those of the authors and do not necessarily reflect the views of the Census Bureau. This paper has been screened to insure that no confidential data are revealed. 


\section{INTRODUCTION}

The widespread dispersal of the immigrants (i.e. the foreign-born population) is probably the most significant demographic development in the United States since the 1990s (Passel and Zimmermann, 2001; Passel and Suro, 2005; Kochhar, 2006). This dispersal has brought new opportunities and challenges to both immigrants themselves and many host communities that used to have little direct contact with people of foreign origin (Hernandez-Leon and Zuniga, 2000; Grey and Woodrick, 2003; Johnson-Webb, 2003; Gozdziak and Bump, 2004; Singer, Hardwick and Brettell, 2008). In a review of research on immigrant assimilation, Mary Waters and Tomas Jimenez (2005) identified this phenomenon as presenting a "golden opportunity" to social scientists for building better empirical and theoretical understandings. In a new book called New Faces in New Places, Douglas Massey and 17 other researchers focused their attention on various aspects of this dispersal (Massey, 2008).

To achieve an in-depth understanding of the mechanisms involved in this dispersal, it is important to examine both the change in the destination choices made by newly-arrived immigrants and the change in the domestic migration of the foreign-born population, using different spatial units such as states, metropolitan areas, and non-metropolitan areas. States are the most frequently used spatial units for the study of the changes in these mechanisms mainly for the following reasons. First, the number and the boundaries of states have remained constant for a long time. Second, large amounts of time series data on not only migration but also relevant socioeconomic variables are available and relatively easy to obtain at the state level. Third, state governments are important political units that have clear legal powers and obligations to carry out a wide range of societal activities. 
On theoretical ground, metropolitan areas are better spatial units than states for research purposes, because they are better proxies for distinct labor markets. However, it is difficult to study the above-mentioned changes at the metropolitan level in the United States, mainly due to the geographic incongruities in publicly available data. For example, the smallest area units, PUMAs, used in the 5 percent Public Use Micro-data Sample (PUMS) of population censuses are not suitable for constructing meaningful metropolitan areas such as those defined by the US Office of Management and Budget (OMB), due to extensive boundary inconsistencies. If we use the PUMS as the data base to uncover migration patterns for the crude PUMA-based approximations to metropolitan area, we will not be able to explain these patterns with variables from other government sources such as employment and income data in the Regional Economic Information System (REIS) files produced by the Bureau of Econonic Analysis (BEA) [ http://www.bea.gov/bea/regional/ docs /cd.cfm].

Believing that metropolitan areas should be used as the basic geographical areas for our migration studies, we overcome this problem by getting permission from the US Census Bureau to access all long-form records of the 1990 and 2000 population censuses via the Census Research Data Center at the University of Michigan. Consequently, we are now able to use official OMB-defined metropolitan areas that were used with the 2000 US Census (276 CMSAs, MSAs and NECMAs) and consistent with data made available by BEA and other agencies. This consistency greatly improved our ability in conducting meaningful multivariate explanations of migration patterns.

Given access to the full long-form records of the 1990 and 2000 censuses, we have planned to carry out in-depth analyses of (1) the destination choices made by newly-arrived immigrants and (2) the domestic migration of foreign-born individuals for the 1985-1990 and 
1995-2000 periods, using metropolitan areas as the basic spatial units. Taking advantage of the fact that the number of long-form records is much bigger than the corresponding PUMS sample size ( $17 \%$ versus $5 \%$ of all census returns), we can transcend the broad ethnic categories (Whites, Blacks, Hispanics, and Asians) used in our previous studies and focus on more homogeneous ethnic groups (e.g. Mexicans, Colombian, Indians, and Vietnamese). The usefulness of studying the migration behaviors of these more homogeneous ethnic groups can be appreciated from the following facts about the 1995-2000 newly-arrived immigrants: those born in Mexico and Vietnam shared the same tendency of picking Los Angeles CMSA as the most preferred destination, whereas those born in India and Colombia shared the same tendency of selecting New York CMSA as their most favorite destination. Furthermore, we learn from the long-form records of the 1990 census that this contrast persisted from the late 1980s.

As a note of clarification, the names of the metropolitan areas mentioned in this paper are abbreviated from their rather long official names. For a longer version of their names, please see Table 1.

Although we are still at an early stage of our analyses, this paper reports on the first set of the findings from our explanatory analysis of destination choices among 276 metropolitan areas made by Mexican-born and Indian-born immigrants who arrived in the United States in 19952000, using a multinomial logit model. The study of the change between 1985-1990 and 19952000 will be reported in another paper.

The main contribution of this paper lies in (1) the characterization and explanation of the sharp contrast in destination choice patterns between the Mexican-born and Indian-born new immigrants and (2) the demonstration of an effective methodology for achieving a better 
understanding of a real-world phenomenon in which the explanatory powers of the explanatory factors overlap substantially.

The organization of the remaining part of the paper is as follows. In section 2, we characterize the observed destination choice patterns. In section 3, we describe the statistical model and its application, including a relatively detailed account of the selection of the explanatory factors. In section 4 , we present the multivariate findings. In section 5 , we provide a concluding discussion. In Appendix A, we make an attempt at persuading other researchers to adopt our research methodology.

\section{CHARACTERIZATION OF THE OBSERVED PATTERNS OF THE DESTINATION CHOICES}

For each of the 1995-2000 newly-arrived immigrants, we restrict the set of potential destinations to be the nation's 276 metropolitan areas discussed above. This restriction implies that we remove those immigrants who went to the non-metropolitan part of the country. For simplicity, we refer to the immigrants in our study as metropolitan-bound immigrants. We further restrict the individuals in our sample to those in the 20-59 age group for two reasons. First, one of our main concerns is about the effects of labor market conditions, which tend to be relatively unimportant for those aged $60+$. Second, with respect to the selective effects of labor market conditions at different levels of educational attainment, we exclude those less than 20

years old, since many are still pursuing their educations at these ages. With respect to place of birth we select only the long-form records of those who were born in Mexico and India. 
The similarities and differences in destination choice patterns between the Mexican-born

and Indian-born metropolitan-bound immigrants can be characterized in the following way

(Table 1).

Table 1. Top 30 metropolitan destinations of the 1995-2000 metropolitan-bound new immigrants (aged 20-59) born in Mexico and India.

\begin{tabular}{|c|c|c|c|c|c|c|c|}
\hline \multirow[b]{2}{*}{ Rank } & \multicolumn{2}{|l|}{ Top 30 Destinations of the $1995-2000$} & Cumulative & \multirow{2}{*}{$\begin{array}{c}\text { Top } 30 \text { Destinations of the } 1995-2000 \\
\text { New Immigrants Born in India }\end{array}$} & \multicolumn{2}{|c|}{ Cumulative } & \multirow{2}{*}{$\begin{array}{r}\text { Cumulative } \\
\text { Gap } \\
\end{array}$} \\
\hline & New Immigrants Born in Mexico & Share & Share & & Share & Share & \\
\hline & & $(\%)$ & $(\%)$ & & (\%) & $(\%)$ & $(\%)$ \\
\hline 1 & Los Angeles-Riverside-Orange County CMSA & 17.49 & 17.49 & New York-Northern NJ-Long Island CMSA & 18.49 & 18.49 & 1.00 \\
\hline 2 & Dallas-Fort Worth, TX CMSA & 7.78 & 25.28 & San Francisco-Oakland-San Jose CMSA & 13.51 & 32.00 & 6.72 \\
\hline 3 & Chicago-Gary-Kenosha CMSA & 7.16 & 32.44 & Chicago-Gary-Kenosha CMSA & 6.68 & 38.68 & 6.24 \\
\hline 4 & Houston-Galveston-Brazoria, TX CMSA & 5.55 & 37.98 & Washington-Baltimore CMSA & 5.41 & 44.08 & 6.10 \\
\hline 5 & San Francisco-Oakland-San Jose CMSA & 5.29 & 43.27 & Los Angeles-Riverside-Orange County CMSA & 4.16 & 48.25 & 4.98 \\
\hline 6 & Phoenix-Mesa, AZ MSA & 4.97 & 48.24 & Boston-Worcester-Lawrence NECMA \#\# & 3.85 & 52.10 & 3.86 \\
\hline 7 & New York-Northern NJ-Long Island CMSA & 4.27 & 52.51 & Dallas-Fort Worth, TX CMSA & 3.63 & 55.72 & 3.22 \\
\hline 8 & Atlanta, GA MSA & 3.58 & 56.08 & Detroit-Ann Arbor-Flint, MI CMSA & 3.56 & 59.28 & 3.20 \\
\hline 9 & Denver-Boulder-Greeley, CO CMSA & 2.72 & 58.81 & Philadelphia-Wilmington-Atlantic City CMSA & 3.09 & 62.37 & 3.56 \\
\hline 10 & San Diego, CA MSA & 2.18 & 60.99 & Houston-Galveston-Brazoria, TX CMSA & 2.37 & 64.74 & 3.75 \\
\hline 11 & Las Vegas, NV-AZ MSA ** & 1.79 & 62.78 & Atlanta, GA MSA & 2.26 & 66.99 & 4.21 \\
\hline 12 & Portland-Salem, OR-WA CMSA & 1.56 & 64.35 & Seattle-Tacoma-Bremerton, WA CMSA & 1.52 & 68.51 & 4.17 \\
\hline 13 & Austin-San Marcos, TX MSA & 1.56 & 65.91 & Minneapolis-St. Paul, MN-WI MSA & 1.45 & 69.97 & 4.06 \\
\hline 14 & Raleigh-Durham-Chapel Hill, NC MSA & 1.24 & 67.14 & Columbus, OH MSA \#\# & 1.14 & 71.11 & 3.97 \\
\hline 15 & Charlotte-Gastonia-Rock Hill, NC-SC MSA ** & 1.10 & 68.24 & Denver-Boulder-Greeley, CO CMSA & 1.00 & 72.12 & 3.87 \\
\hline 16 & El Paso, TX MSA ** & 1.08 & 69.33 & Raleigh-Durham-Chapel Hill, NC MSA & 0.95 & 73.06 & 3.74 \\
\hline 17 & McAllen-Edinburg-Mission, TX MSA ** & 1.03 & 70.35 & Phoenix-Mesa, AZ MSA & 0.94 & 74.00 & 3.65 \\
\hline 18 & Salt Lake City-Ogden, UT MSA ** & 1.03 & 71.38 & Cleveland-Akron, OH CMSA \#\# & 0.92 & 74.92 & 3.54 \\
\hline 19 & Greensboro--Winston-Salem—High Point MSA ** & 0.97 & 72.35 & Pittsburgh, PA MSA \#\# & 0.87 & 75.80 & 3.45 \\
\hline 20 & Fresno, CA MSA ** & 0.97 & 73.32 & Sacramento-Yolo, CA CMSA & 0.82 & 76.61 & 3.29 \\
\hline 21 & Seattle-Tacoma-Bremerton, WA CMSA & 0.93 & 74.25 & Austin-San Marcos, TX MSA & 0.81 & 77.43 & 3.18 \\
\hline 22 & San Antonio, TX MSA ** & 0.91 & 75.16 & Portland-Salem, OR-WA CMSA & 0.80 & 78.22 & 3.06 \\
\hline 23 & Washington-Baltimore CMSA & 0.80 & 75.96 & Miami-Fort Lauderdale, FL CMSA & 0.75 & 78.97 & 3.01 \\
\hline 24 & Salinas, CA MSA ** & 0.79 & 76.75 & Cincinnati-Hamilton, OH-KY-IN CMSA \#\# & 0.72 & 79.69 & 2.94 \\
\hline 25 & Minneapolis-St. Paul, MN-WI MSA & 0.74 & 77.49 & Kansas City, MO-KS MSA & 0.64 & 80.33 & 2.84 \\
\hline 26 & Sacramento-Yolo, CA CMSA & 0.72 & 78.21 & San Diego, CA MSA & 0.60 & 80.93 & 2.72 \\
\hline 27 & Philadelphia-Wilmington-Atlantic City CMSA & 0.68 & 78.89 & St. Louis, MO-IL MSA \#\# & 0.56 & 81.50 & 2.61 \\
\hline 28 & Kansas City, MO-KS MSA & 0.65 & 79.53 & Tampa-St. Petersburg-Clearwater, FL MSA \#\# & 0.55 & 82.05 & 2.51 \\
\hline 29 & Detroit-Ann Arbor-Flint, MI CMSA & 0.59 & 80.13 & Milwaukee-Racine, WI CMSA \#\# & 0.55 & 82.59 & 2.47 \\
\hline 30 & Miami-Fort Lauderdale, FL CMSA & 0.56 & 80.68 & Hartford, CT NECMA \#\# & 0.51 & 83.11 & 2.42 \\
\hline
\end{tabular}

Note: ${ }^{* *}$ indicates the metros that are not in the set of the 30 most favorite destinations of the newly-arrived Indian-born immigrants.

\#\# indicates the metros that are not in the set of the 30 most favorite destinations of the newly-arrived Mexican-born immigrants.

First, both groups of new immigrants were heavily concentrated into a few destinations.

More than $50 \%$ of both ethnic groups ended up in the top 7 destinations, with Chicago CMSA 
being the third most preferred destination. The share by the top 5 destinations was $43.3 \%$ for those from Mexico and $48.3 \%$ for those from India. It is useful to note that there were other ethnic groups with much greater concentration in their destination choice patterns. The proportions of their Cuban-born and Colombian-born counterparts going to the top 5 destinations were as high as $80.3 \%$ and $67 \%$, respectively. For all foreign-born new immigrants (also aged 20-59), the share of the top 5 destinations was $42.7 \%$.

Second, the most important destinations differed substantially between the two ethnic groups. Los Angeles CMSA got the lion's share (17.5\%) of those from Mexico but only a moderate share of those from India (4.2\%), whereas New York CMSA got the lion's share $(18.5 \%)$ of those from India but only a moderate share of those from Mexico (4.3\%). Dallas CMSA was the second most important destination for those from Mexico (7.8\%) but the $7^{\text {th }}$ destination for those from India (3.6\%). In contrast, San Francisco CMSA was the second most preferred destination for those from India (13.5\%) but the $5^{\text {th }}$ destination for those from Mexico $(5.3 \%)$.

Third, the metropolitan areas that were in the set of the top 30 destinations of those from Mexico but not in the set of the top 30 destinations of those from India were all concentrated in the western part of the US, except for Charlotte MSA and Greensboro MSA (two of the "new destinations" in the South Atlantic Division). There were 9 such destinations, including 1 at the border of Nevada and Arizona (Las Vegas MSA, ranked 11th), 3 in Texas (El Paso MSA, McAllen MSA, and San Antonio MSA), 1 in Utah (Salt Lake City MSA), and 2 in California (Fresno MSA and Salina MSA).

Fourth, the metropolitan areas that were in the set of the top 30 destinations of those from India but not in the set of the top 30 destinations of those from Mexico were all concentrated in 
the eastern part of the US. There were 9 such destinations, including 3 in the Northeast Region (Boston NECMA, ranked 6th, Pittsburg MSA, and Hartford NECMA), 5 in the Midwest Region (Columbus MSA, Cleveland CMSA, Cincinnati CMSA, St. Louis MSA, and Milwaukee CMSA), and 1in Florida (Tampa MSA).

Fifth, the Mexican and Indian new immigrants shared strong preferences for the west coast. Four major metropolitan areas of California (Los Angeles CMSA, San Francisco CMSA, San Diego MSA, and Sacramento CMSA) were in the set of the top 30 destinations of both groups. So were the largest metropolitan areas of the states of Washington and Oregon (Seattle CMSA and Portland CMSA).

Sixth, the Mexican and Indian new immigrants were both important contributors to channeling of the foreign-born into Atlanta MSA and Raleigh MSA that have long been major net gainers of White and Black domestic migrants. Atlanta MSA attracted 3.6\% of those born in Mexico and $2.3 \%$ of those born in India. It was the $8^{\text {th }}$ destination for the former and the $11^{\text {th }}$ destination for the latter.

The educational attainment of the new immigrants is an important personal attribute to consider for two main reasons. First, it affects the quality of human capital and the burden on the social service systems of the destination communities. In general, the long-term settlement of poorly educated immigrants tends to have negative effects by overburdening local social service systems and by slowing down the assimilation process, although they may help sustain local industries that are subject to fierce competitions from low-cost domestic or foreign producers. Second, it affects the ways in which the destination choice behaviors of the new immigrants respond to various place attributes of the potential destinations (Liaw and Frey, 2007). It is not 
surprising that the destination choice patterns of new immigrants tend to vary systematically with their levels of educational attainment.

\begin{tabular}{|c|c|c|c|c|c|c|c|c|c|c|c|c|c|}
\hline \multirow{2}{*}{$\begin{array}{l}\text { Educational } \\
\text { Attainment }\end{array}$} & \multicolumn{2}{|c|}{ 1st Destination } & \multicolumn{2}{|c|}{ 2nd Destination } & \multicolumn{2}{|c|}{ 3rd Destination } & \multicolumn{2}{|c|}{ 4th Destination } & \multicolumn{2}{|c|}{ 5th Destination } & \multirow{2}{*}{$\begin{array}{r}\text { Top 5's } \\
\text { Share } \\
\end{array}$} & \multirow{2}{*}{$\begin{array}{l}\text { Relative } \\
\text { Entropy }\end{array}$} & \multirow{2}{*}{$\begin{array}{r}\text { Total } \\
\text { Immigrants }\end{array}$} \\
\hline & Name & Share & Name & Share & Name & Share & Name & Share & Name & Share & & & \\
\hline & & $(\%)$ & & (\%) & & $(\%)$ & & $(\%)$ & & (\%) & (\%) & $(\%)$ & (persons) \\
\hline \multicolumn{14}{|c|}{ Born in Mexico } \\
\hline LT High Sch. & $\begin{array}{l}\text { Angeles } \\
\text { Los }\end{array}$ & 18.5 & Dallas-F-W & 8.3 & Chicago & 6.7 & $\begin{array}{l}\text { Houston } \\
\text { San }\end{array}$ & 5.7 & Francisco & 5.1 & 44.3 & 65.1 & 763,293 \\
\hline High School & $\begin{array}{l}\text { Angeles } \\
\text { Los }\end{array}$ & 15.6 & Chicago & 8.9 & Dallas-F-W & 6.5 & Francisco & 5.8 & $\begin{array}{l}\text { New York } \\
\text { San }\end{array}$ & 5.8 & 42.6 & 65.9 & 192,627 \\
\hline Some College & $\begin{array}{l}\text { Angeles } \\
\text { Los }\end{array}$ & 16.5 & Chicago & 7.8 & Dallas-F-W & 6.7 & Houston & 5.6 & Francisco & 5.6 & 42.3 & 66.0 & 79,598 \\
\hline Bachelor & $\begin{array}{l}\text { Angeles } \\
\text { Los }\end{array}$ & 12.3 & Chicago & 6.6 & Houston & 6.0 & New York & 5.9 & Dallas-F-W & 5.7 & 36.5 & 68.7 & 34,232 \\
\hline Master's + & Angeles & 12.6 & Dallas-F-W & 7.3 & Houston & 6.7 & Chicago & 5.8 & New York & 5.0 & 37.6 & 67.5 & 22,793 \\
\hline Total & $\begin{array}{l}\text { Los } \\
\text { Angeles }\end{array}$ & 17.5 & Dallas-F-W & 7.8 & Chicago & 7.2 & Houston & 5.6 & $\begin{array}{l}\text { San } \\
\text { Francisco }\end{array}$ & 5.3 & 43.3 & 65.9 & $1,092,543$ \\
\hline \multicolumn{14}{|c|}{ Born in India } \\
\hline LT High Sch. & $\begin{array}{l}\text { New } \\
\text { York } \\
\text { New }\end{array}$ & 25.8 & $\begin{array}{l}\text { San } \\
\text { Francisco }\end{array}$ & 8.8 & Chicago & 8.2 & $\begin{array}{l}\text { Los } \\
\text { Angeles } \\
\text { Los }\end{array}$ & 6.0 & Washington & 4.7 & 53.4 & 57.3 & 18,467 \\
\hline High School & $\begin{array}{l}\text { York } \\
\text { New }\end{array}$ & 25.1 & Chicago & 9.2 & San Francisco & 8.5 & $\begin{array}{l}\text { Angeles } \\
\text { Los }\end{array}$ & 5.6 & Philadelphia & 4.8 & 53.3 & 59.2 & 14,135 \\
\hline Some College & $\begin{array}{l}\text { York } \\
\text { New }\end{array}$ & 19.9 & $\begin{array}{l}\text { Chicago } \\
\text { San }\end{array}$ & 9.4 & San Francisco & 9.3 & Angeles & 6.1 & Washington & 5.2 & 49.8 & 63.8 & 19,138 \\
\hline Bachelor & $\begin{array}{l}\text { York } \\
\text { New }\end{array}$ & 17.7 & $\begin{array}{l}\text { Francisco } \\
\text { San }\end{array}$ & 14.9 & Chicago & 6.1 & Washington & 5.5 & Boston & 4.1 & 48.4 & 62.9 & 110,838 \\
\hline Master's + & York & 16.6 & Francisco & 14.4 & Chicago & 6.1 & Washington & 5.7 & Boston & 4.5 & 47.3 & 63.8 & 89,966 \\
\hline Total & $\begin{array}{l}\text { New } \\
\text { York }\end{array}$ & 18.5 & $\begin{array}{l}\text { San } \\
\text { Francisco }\end{array}$ & 13.5 & Chicago & 6.7 & Washington & 5.4 & $\begin{array}{l}\text { Los } \\
\text { Angeles }\end{array}$ & 4.2 & 48.2 & 63.5 & 252,544 \\
\hline
\end{tabular}

We see in Table 2 that the destination choice patterns of the 1995-2000 newly arrived metropolitan-bound Mexican and Indian immigrants tended to be less concentrated into a few places at higher levels of education. The share of those from Mexico by Los Angeles CMSA was as high as $18.5 \%$ for those without a high school diploma but was less than $13 \%$ for those with at least a Bachelor's degree. The share of those from India by New York CMSA was as high as $25.8 \%$ for those without a high school diploma but was less than $17 \%$ for those with at least a Master's degree. For those from Mexico, the joint share of the top 5 destinations decreased from $44.3 \%$ at the lowest educational level to less than $38 \%$ at the highest educational level. For those from India, the joint share of the top 5 destinations decreased from $53.4 \%$ at the lowest educational level to less than $48 \%$ at the highest educational level. 
To reflect the full range of choices among the 276 metropolitan destinations, we use relative entropy, which is defined in the following way. For a given group of immigrants, let $\mathrm{P}[\mathrm{j}]$ be the proportional share by the jth metropolitan area so that its value is bounded between 0 and 1. Then the relative entropy for characterizing the destination choice pattern of this group is defined as:

$$
\mathrm{E}=\left\{\sum \mathrm{P}[\mathrm{j}] * \log _{2}(1 / \mathrm{P}[\mathrm{j}])\right\} / \log _{2}(276) * 100 \%
$$

where the summation is across all 276 potential destinations. Since the value of the entropy shown within the braces can never be less than 0 (when all immigrants go to only one state) or greater than $\log _{2}$ (276) (when all potential destinations have the same share of the immigrants), the value of the relative entropy is conveniently bounded between $0 \%$ and $100 \%$. Since it depends on the proportional shares of all 276 metropolitan destinations, the relative entropy is a measure of overall dispersal.

The values of relative entropy in Table 2 show that there was a general tendency for the overall dispersal to be higher at higher levels of educational attainment. For those from Mexico, the relative entropy increased from $65.1 \%$ at the lowest level of educational attainment to $68.7 \%$ at the Bachelor's level and then decreased slightly to $67.5 \%$ at the Master's + level. For those from India, the relative entropy increased from $57.3 \%$ at the lowest level of educational attainment to $63.8 \%$ at the level of some college education and then remained at a plateau at higher levels of educational attainment.

An important point we learn from Table 2 is that the effect of ethnicity on destination choice behaviors was much greater than that of educational attainment. For example, for those from Mexico, Los Angeles CMSA was the most preferred destination at all levels of educational 
attainment. In contrast, for those from India, New York CMSA was the top destination at all levels of educational attainment.

It is useful to note that among all groups of the new immigrants, those from Mexico were most poorly educated, whereas those from India were best educated. As many as $70 \%$ of those from Mexico did not have a high school diploma. In contrast, among those from India, $44 \%$ had a Bachelor's degree and 36 had a Master's, professional, or doctoral degree.

Since the Mexican-born mostly belonged to the lowest level of educational attainment, the top 5 destinations of all Mexican-born individuals turned out to be identical to those of the least educated: (1) Los Angeles CMSA, (2) Dallas CMSA, (3) Chicago CMSA, (4) Houston CMSA, and (5) San Francisco CMSA.

Since the Indian-born mostly belonged to the highest two levels of educational attainment, the top 5 destinations of all Indian-born individuals turned out to be identical to those at the two highest level of educational attainment: (1) New York CMSA, (2) San Francisco CMSA, (3) Chicago CMSA, (4) Washington CMSA, and (5) Boston NECMA. All of these 5 destinations were high income metropolitan areas.

\section{DESIGN OF THE DESTINATION CHOICE MODEL}

\subsection{Formulation and Application of the Destination Choice Model}

Our multivariate statistical model is a multinomial logit model formulated in the following way. For an immigrant of ethnic group $i$ with personal attributes $s$, we specify that the migration behaviour depends on a set of destination choice probabilities, $P(j \mid s, i)$ for all potential destinations $j$. These probabilities are specified to be functions of observable explanatory variables in the following form 


$$
P(j \mid s, i)=\frac{\exp \left(b^{\prime}[i] x[j, s, i]\right)}{\sum_{k} \exp \left(b^{\prime}[i] x[k, s, i]\right)}
$$

where $x[j, s, i]$ is a column-vector of observable explanatory variables; $b^{\prime}[i]$ is a row-vector of unknown coefficients for ethnic group $i$; and the summation in the denominator is across all 276 potential destinations.

In applying this model, we assume that the choices of destinations made by the new immigrants were affected by both the personal attributes of the immigrants and the place attributes of the alternatives in the choice set. To make the computation fast without losing any relevant information, we tabulated the weights of the individual long-form records into a multidimensional table, with the dimensions being (1) ethnicity (Mexican-born, Indian-born), (2) educational attainment (less than high school graduation, high school graduation, some college education, college graduation, Master+) $)^{1}$, (3) five-year age groups $(20-24,25-29, \ldots, 54-59)$, (4) gender (female, male), and (5) metropolitan area of residence as of the census date.

Assuming that the migration behaviors of all persons in the same cell of the multidimensional table depend on the same $P(j \mid s, i)$, we estimate the unknown coefficients in equation (1) for each of the two ethnic groups separately by the maximum likelihood method.

In the model, each personal attribute is represented by a set of dummy variables. These dummy variables are entered into the logit model as interactions with the variables representing place attributes. An interaction between two variables is simply the product of the two variables. For example, to test the idea that the growth of the best paying jobs (a place attribute) has a particularly strong drawing power on the best educated Indians, we use an interaction in the

\footnotetext{
${ }^{1}$ The "Master+" category includes those with Master's, professional, or doctoral degree. Interestingly, we found in a multivariate model that among the foreign-born, those with a professional degree were rewarded with a much higher salary than were those with a Master's or doctoral degree.
} 
model for Indians that is the product of the following variables: Job increase in the $10^{\text {th }}$ wage decile, and a dummy variable representing the educational attainment of at least a Bachelor's degree. If the estimated coefficient of this interaction turns out to be positive, and if the associated t-ratio (i.e. the estimated coefficient divided by its asymptotic standard error) is greater than or equal to 2.0 , we may then infer that the idea is substantiated by the empirical data. Because our sample size is very large, the t-ratio can be considered as having a standard normal distribution so that a magnitude of at least 2.0 can be considered as an indication of statistical significance. Note that in order to avoid artificial inflation of the magnitude of the t-ratios, we had scaled the weights by their mean value so that the sum of the new weights equal to the number of long-form records in our sample, before the maximum likelihood method was applied.

In constructing a relatively concise specification of the model (to be called the best specification for simplicity) for each ethnic group, we only include the explanatory variables whose estimated coefficients are statistically significant and substantively sensible.

The goodness of fit of a given specification of the model is to be measured by

$$
\rho^{2}=1-L_{g} / L_{o}
$$

where $L_{g}$ is the maximum log-likelihood of the given specification, and $L_{o}$ is the log-likelihood of the corresponding null model (i.e. the model with $b^{\prime}[i]=0$ ). Note that the ceiling of $\rho^{2}$ is much less than 1.0 so that a value of 0.2 may indicate a very good fit (McFadden, 1974).

To help assess the relative importance of one subset of explanatory variables (say labor market variables) against another subset, we will delete the two subsets of variables in turn from the best specification and then compare the resulting decreases in $\rho^{2}$ : the greater the decrease, the more important the deleted subset of variables. The decrease in $\rho^{2}$ resulting from the deletion of a subset of explanatory variables is called marginal contribution in $\rho^{2}$. 
It is important to note that when an explanatory factor (e.g. a subset of labor market variables) is deleted from the best specification, the values of the coefficients of the remaining explanatory variables that are generated by the maximum likelihood method will become different from those in the best specification, unless the explanatory power of the deleted factor does not overlap with those of the remaining explanatory variables. When the overlap is substantial, the resulting marginal contribution in $\rho^{2}$ will seriously understate the explanatory power of the deleted factor. One way to avoid getting such a misleading result is to assess the importance of a deleted factor by keeping the estimated coefficients of the remaining explanatory variables of the best specification unchanged. These two alternative methods of assessing the explanatory power of a deleted factor are called (1) maximizing method, and (2) fixed-coefficient method, respectively (Liaw and Ishikawa, 2008). Our assessment to be presented later is based on the latter method. The advantages of using both of these methods for achieving a better understanding of the complexities of real-world processes are highlighted in Appendix A.

\subsection{Specification of Place Attributes}

It has been well demonstrated that the destination choice behaviors of both new immigrants and domestic migrants of minority ethnic groups are subject to the drawing power of co-ethnic communities (Liaw and Frey 1996 and 1998; Frey and Liaw, 2005; Xu and Liaw, 2006; Liaw and Ishikawa, 2008). There are various reasons for this drawing power (Portes, 1995; Light, 2006; Massey, 2008). Friends and relatives in co-ethnic communities can provide relatively reliable information on employment opportunities in both enclave economy and formal labor market. They can also provide shelter and support for the initial settlement. Co-ethnics can also be a source of social capital for setting up small businesses. To represent the drawing power of co-ethnic communities, we specify the following explanatory factor. 
Ethnic similarity: For the immigrants of a specific ethnic group arriving in 1995-2000, the value of this place attribute for the jth potential destination is the natural log of a location quotient computed in the following way. The numerator of the quotient is the jth potential destination's share of all the foreign-born members of this specific ethnic group who resided in the 276 metropolitan areas in 1995, whereas the denominator of the quotient is the jth potential destination's share of all individuals who resided in the 276 metropolitan areas in 1995 . The values are computed from the long-form records of the 2000 population census. If the location quotient of the jth potential destination is greater than 1 , then it had more than its "fair" share of the immigrants' co-ethnics in its 1995 population. If the value is less than 1, the opposite is true. The $\log$ transformation of the location quotient moves the reference value from 1 to 0 . The coefficient of this variable is expected to be positive.

We see in Table 3 that the metropolitan areas with high location quotients for the Mexican-born population tended to be quite different from the metropolitan areas with high location quotients for the Indian-born population. It is not surprising that most of the metropolitan areas with very high location quotients for Mexicans such as McAllen MSA (9.08), Laredo (8.76), and El Paso (7.74) are located on or near the border between Mexico and the US. In contrast, the metropolitan areas with relatively high location quotients for Indians are widely scattered. The very high Indian location quotient of Yuba CMA (9.50) is rooted in a Sikh community established in the late $19^{\text {th }}$ century. ${ }^{2}$ But, most of the metropolitan areas with relatively high Indian location quotients are large places with many professional jobs (e.g. New York, San Francisco, Chicago, Houston, Washington, and Philadelphia) or relatively small places with large post-secondary educational and research institutes (e.g. Lafayette in Indiana,

2 Annual Sikh parade has long been an important festival in Yuba City and has attracted many Sikh's from allover the world. In 2007, it was reported that the $28^{\text {th }}$ Annual Sikh Parade attracted about 75,000 - 80,000 Sikh and nonSikh spectators (www.emediawire.com/releases/2007/11/emw566755.htm). 
State College in Pennsylvania, Bryan-College Station in Texas, and Champaign-Urbana in Illinois). Our examination of the post-immigration relocation of the foreign-born reveals that such "college towns" had very high 1995-2000 out-migration rates for the Indian-born, suggesting that they were used as "way stations" by many well-educated Indian immigrants.

Table 3. The 30 metropolitan areas with the highest location quotients (LQ) for the Mexican-born and Indian-born residents in 1995.

\begin{tabular}{|c|c|c|c|c|c|c|}
\hline \multirow[b]{2}{*}{ Rank } & \multicolumn{3}{|c|}{ Mexican-born Population in 1995} & \multicolumn{3}{|c|}{ Indian-born Population in 1995} \\
\hline & 1995 Place of Residence & Pop. Size & LQ & 1995 Place of Residence & Pop. Size & LQ \\
\hline 1 & McAllen-Edinburg-Mission, TX MSA ** & 150,073 & 9.08 & Yuba City, CA MSA & 4,092 & 9.50 \\
\hline 2 & Laredo, TX MSA ** & 48,793 & 8.76 & New York-Northern NJ-Long Island CMSA \#\# & 171,269 & 2.63 \\
\hline 3 & El Paso, TX MSA ** & 162,564 & 7.74 & San Francisco-Oakland-San Jose CMSA & 53,466 & 2.50 \\
\hline 4 & Brownsville-Harlingen-San Benito, TX MSA ** & 77,925 & 7.70 & Merced, CA MSA & 1,544 & 2.47 \\
\hline 5 & Yuma, AZ MSA ** & 30,049 & 6.70 & Chicago-Gary-Kenosha CMSA & 57,473 & 2.03 \\
\hline 6 & Salinas, CA MSA ** & 74,387 & 6.53 & Lafayette, IN MSA \#\# & 888 & 1.72 \\
\hline 7 & Visalia-Tulare-Porterville, CA MSA ** & 62,703 & 5.57 & Houston-Galveston-Brazoria, TX CMSA & 23,166 & 1.70 \\
\hline 8 & Las Cruces, NM MSA ** & 27,900 & 5.28 & Washington-Baltimore CMSA \#\# & 37,725 & 1.65 \\
\hline 9 & Merced, CA MSA & 30,841 & 4.99 & State College, PA MSA \#\# & 603 & 1.61 \\
\hline 11 & Yakima, WA MSA ** & 31,059 & 4.51 & Champaign-Urbana, IL MSA \#\# & 797 & 1.54 \\
\hline 12 & Los Angeles-Riverside-Orange County CMSA & $2,222,480$ & 4.51 & Modesto, CA MSA & 2,003 & 1.51 \\
\hline 13 & Santa Barbara-Santa Maria-Lompoc, CA ** & 52,781 & 4.32 & Fresno, CA MSA & 4,207 & 1.48 \\
\hline 14 & Bakersfield, CA MSA & 78,571 & 3.96 & lowa City, IA MSA \#\# & 440 & 1.34 \\
\hline 15 & Modesto, CA MSA & 42,657 & 3.24 & Stockton-Lodi, CA MSA & 2,211 & 1.34 \\
\hline 16 & San Diego, CA MSA ** & 268,083 & 3.24 & Bellingham, WA MSA \#\# & 625 & 1.33 \\
\hline 17 & Stockton-Lodi, CA MSA & 45,997 & 2.82 & Philadelphia-Wilmington-Atlantic City \#\# & 25,451 & 1.33 \\
\hline 18 & Houston-Galveston-Brazoria, TX CMSA & 364,749 & 2.70 & Detroit-Ann Arbor-Flint, MI CMSA \#\# & 19,808 & 1.17 \\
\hline 19 & Odessa-Midland, TX MSA ** & 18,283 & 2.41 & Dallas-Fort Worth, TX CMSA & 16,891 & 1.15 \\
\hline 20 & Yuba City, CA MSA & 9,979 & 2.34 & Rochester, MN MSA \#\# & 419 & 1.13 \\
\hline 21 & Richland-Kennewick-Pasco, WA MSA ** & 13,053 & 2.30 & Raleigh-Durham-Chapel Hill, NC MSA \#\# & 3,639 & 1.13 \\
\hline 24 & Tucson, AZ MSA ** & 52,119 & 2.16 & Sacramento-Yolo, CA CMSA \#\# & 5,435 & 1.04 \\
\hline 25 & San Antonio, TX MSA ** & 99,342 & 2.12 & Columbia, MO MSA \#\# & 403 & 1.03 \\
\hline 26 & San Francisco-Oakland-San Jose CMSA & 392,463 & 1.85 & Bakersfield, CA MSA & 2,066 & 1.03 \\
\hline 27 & Las Vegas, NV-AZ MSA ** & 70,791 & 1.85 & Los Angeles-Riverside-Orange County CMSA & 50,433 & 1.01 \\
\hline 28 & Chicago-Gary-Kenosha CMSA & 494,714 & 1.77 & Lawrence, KS MSA \#\# & & . \\
\hline 29 & Naples, FL MSA ** & 10,961 & 1.74 & Hartford, CT NECMA \#\# & 3,523 & 1.00 \\
\hline 30 & Reno, NV MSA ** & 16,232 & 1.69 & Austin-San Marcos, TX MSA \#\# & 3,227 & 0.97 \\
\hline
\end{tabular}

Note: ${ }^{* *}$ indicates the metros that are not in the set of the top 30 for the Indian-born.

\#\# indicates the metros that are not in the set of the top 30 for the Mexican-born.

The data used to construct this table are the long-form records of the 2000 population census. The Indian-born population size of Lawrence MSA and the corresponding location quotient were suppressed in the disclosure process. 
It is likely that the primary motivation for most immigrants to come to the United States is to look for income-generating jobs. The new immigrants' choices of metropolitan destinations can be expected to be influenced by the employment and income prospects of the potential destinations. To represent income prospect, we use the following place attribute.

Wage level: For each metropolitan area, the value of this place attribute is specified as its 1995 wage and salary per job. The unit is $\$ 1,000$. The data are downloaded on October 3, 2006 from the website of Regional Economic Accounts, BEA, Department of Commerce: http://www.bea.gov/bea/regional/reis/default.cfm?catable=CA30. The name of the variable in the original data source is "Average wage and salary disbursements", which belongs to a table called "Regional economic profile". The 5 metropolitan areas with the highest wage levels are (1) New York CMSA (\$37,500), (2) San Francisco CMSA (\$35,661), (3) Hartford NECMA (\$33,337), (4) Detroit CMSA $(\$ 33,328)$, and $(5)$ Kokomo MSA $(\$ 32,957)$ in Indiana. The 5 metropolitan areas with the lowest wage levels are (1) Lawrence MSA $(\$ 19,034)$ in Kansas, (2) Laredo MSA $(\$ 18,919)$ in Texas, (3) Brownsville MSA $(\$ 18,206)$ in Texas, $(4)$ McAllen MSA $(\$ 18,189)$ in Texas, and (5) Myrtle Beach MSA $(\$ 18,099)$ in South Carolina.

Both employment growth rate and unemployment rate have been used as proxies for employment opportunities. But, it is worth keeping in mind that when many young adults in an economically stagnant metropolitan area decide to leave soon after finishing schooling, the metropolitan area's unemployment rate may become unusually low so that unemployment rate may become a very misleading indicator of the metropolitan's employment opportunities. In line with this reasoning, we were not surprised by the finding of Liaw and Frey (2007) that the 1995 unemployment rate did not have statistical significant effect on the 1995-2000 new immigrants 
in their choices of the states as their destinations. Therefore, we decided not to use unemployment rate as one of the explanatory variables.

In light of Parrado and Kandel's (2008) account of the attraction of low-skilled Hispanic immigrants by the employment opportunities in construction and meat processing industries, and news reports about the massive recruitment of computer scientists from India by IT firms in the Silicon Valley, it seemed reasonable to start our analysis by using the 1995-2000 industryspecific employment growth rates as proxies for employment opportunities at the potential destinations. Unfortunately, the estimated coefficients of these variables turned out to be of little interpretive meanings. We suspect that this disappointing finding is due to the following two reasons. First, the BEA data on the 1995 and 2000 industry-specific employment sizes are available for only broad categories of industries such as manufacturing and service. With such data, it is impossible to specify the employment growth rates of such industries as meat processing and hospitality that are expected to have strong attractive effects on low-skilled immigrants, especially those from Mexico. Second, within each industry, there are both lowskilled and high-skilled jobs that tend to attract poorly-educated and well-educated immigrants, respectively. Since the BEA employment data are not stratified by occupational status, they are incapable of showing the differential growths of low-skilled and high-skilled jobs within each industry.

Fortunately, Wright and Dwyer (2003) and Bean, Leach, and Lowell (2004) have demonstrated a more helpful way of measuring employment growths. Inspired by Joseph Stiglitz's example, Wright and Dwyer started by defining a job type as a cell in the crosstabulation of employees by industry and occupation. For each job type, they used the median hourly wage of employees as a measure of the quality of the jobs in it. The job types were 
ranked by median hourly wage in ascending order and then divided into quintiles in terms of the number of employees. Using CPS data on full-time employees aged 18-64, they were able to show that the 1992-2000 employment expansion had a pattern of asymmetrical polarization: very strong growth at the top tier, moderately strong growth at the bottom, and very weak growth in the middle. Of particular interest is their finding that Hispanic immigrants accounted for as much as $47 \%$ of the $1994-2000$ job expansion in the bottom wage quintile. Due to the relatively small sample size of CPS, their study did not specifically deal with Asian immigrants.

Taking advantage of the relatively large sample size of the micro data of the 1990 and 2000 population censuses in IPUMS (Integrated Public Use Microdata Sample), Bean, Leach, and Lowell also defined a job type as a cell in the cross-tabulation of full-time employees (aged 18-64) by industry and occupation. Instead of median wage, they used mean wage to represent the quality of a job type. Their finding added the additional insight that in the 1990-2000 employment expansion, foreign-born male Asians were strongly over-represented in the top quintile.

Since the sample sizes of neither CPS nor IPUMS are large enough for generating reliable and specific information on the employment changes of the 276 metropolitan areas used in our study, we decided to rely on the long-form records of the 1990 and 2000 censuses to quantify the relative changes in employment opportunities among the metropolitan areas in the 1990s in the following way.

First, in each census, the long-form records are stratified by gender. For all individuals with known 3-digit industry and occupation codes in each gender-specific stratum, we tally the weights of the individual records into the cells of the cross-tabulation by industry and occupation. Each of these cells is called a job type. The quality of each job type is represented by the 
weighted average of the wage per week of all individuals in the job type who had a positive wage income and at least 10 weeks of work in the previous 12 months. ${ }^{3}$ The job types are then ranked by the average weekly wage in descending order and grouped into wage deciles in terms of the weights of the of workers. Because we use the most detailed industry and occupation codes, each wage decile contains almost exactly $10 \%$ of the (weighted) workers. The wage decile code of each job type is then assigned to every worker in the job type, with 1 representing the decile with the lowest wage.

Second, in each census, the weights of gender-specific workers with non-missing industry and occupation codes in each of the 276 metropolitan areas are tallied into the genderspecific wage deciles in term of their weights. The resulting percentage distributions of workers among the wage deciles reveal substantial inter-metropolitan variation in the composition of jobs with different income generating capacities. For example, according to the 2000 census, as many as $17.9 \%$ of the male workers of San Francisco CMSA belonged to the top wage decile, whereas as many as $25.6 \%$ of the male workers of Visalia MSA (also in California) belonged to the bottom wage decile. By the way, here we see that intrastate variation in labor markets can be tremendous, suggesting the importance of using metropolitan areas as the basic geographical units in migration studies.

Third, for each of the 276 metropolitan areas, we create 10 gender-specific variables to represent the changing employment structure between 1990 and 2000. Each of these variables correspond to each of the wage deciles and is computed from subtracting (1) the percentage share of a wage decile in 2000 by (2) the percentage share of the same wage decile in 1990 . We

\footnotetext{
${ }^{3}$ The census questionnaire does not elicit the information on weekly wage directly. Instead, it elicits information on (1) the wage and salary income in the previous 12 months and (2) the weeks of work in the previous 12 months. For each long-form record, we compute the weekly wage by dividing (1) by (2). Since we found that for some individuals with very few weeks of work the computed weekly wage can be very misleading, we decided to compute the average weekly wage of each job type from only the records of the workers who worked for at least 10 weeks.
} 
call the resulting variable for the jth wage decile as the "job increase in jth wage decile". From these variables, we find that relative to the whole country, the employment structure improved for San Francisco CMSA and deteriorated for Los Angeles CMSA between 1990 and 2000. For males, the share of workers by the top wage decile increased by 3.4 percentage point for San Francisco CMSA and decreased by 1.6 percentage point for Los Angeles CMSA. For females, the corresponding figures are 2.8 and -0.8 , respectively. Figure 1 shows that relative to the male jobs in the whole country, both San Francisco and Los Angeles had fewer male jobs in the middle-range wage deciles in both 1990 and 2000. It also shows that the distribution of male jobs became more U-shaped from 1990 to 2000 in both San Francisco and Los Angeles, with San Francisco benefiting from a substantial expansion in the top wage decile and Los Angeles experiencing a marked expansion in the second lowest wage decile.

In light of the findings of Wright and Dwyer (2003) and Bean, Leach, and Lowell (2004) that in the employment expansion of the 1990s, Hispanic and Asian immigrants were disproportionately concentrated in the bottom and top wage quintile, respectively, we select the following variables to study of effects of differential job expansions on the new immigrants from Mexico and India.

Job increases in the bottom three and top three Wage Deciles. We expect that those from Mexico were more subject to the positive effects of the bottom three wage deciles, whereas those from India were more subject to the positive effects of the top three wage deciles. 


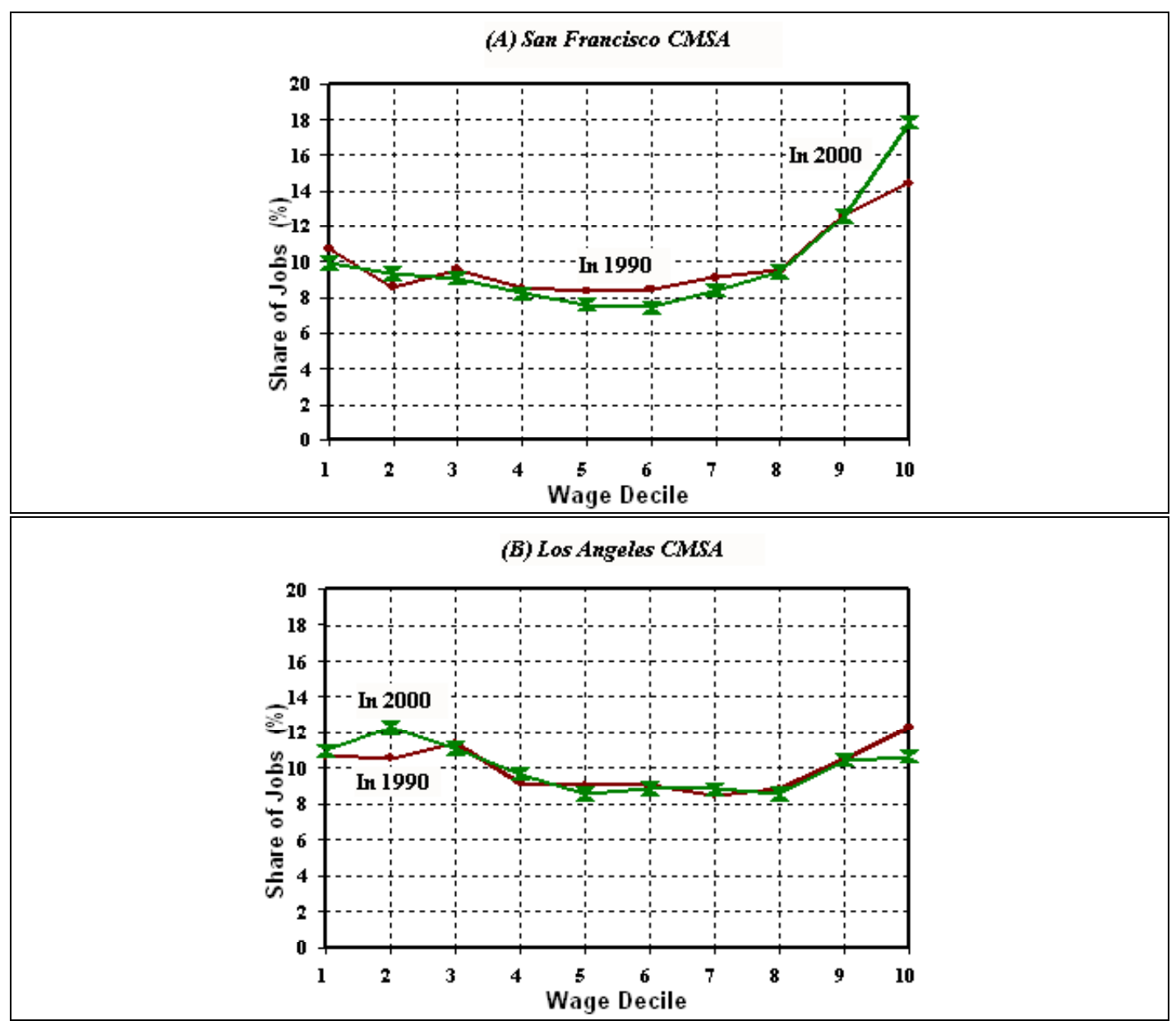

Figure 1. The 1990 and 2000 distributions of male jobs among the wage deciles in two CMSAs, with the wage deciles defined by the male workers of the United States. 
Realizing that the economic recession of the early 1990s was more severe in some parts of the country (especially southern California) than other parts (e.g. Houston and Dallas in Texas), we also use the following variable as a temporally better matched variable for representing intermetropolitan variation in the overall employment changes between 1995 and 2000.

Total employment growth rate: For each of the 276 metropolitan areas, this place attribute is the metropolitan area's 1995-2000 growth rate of total employment (i.e. the employment of all industries combined). The unit is $\%$ per year. The growth rate is computed from the data on the 1995 and 2000 employment sizes that were downloaded on October 6, 2006 from http://www.bea.gov/bea/regional/reis/Default.cfm?catable=CA25. The original data belong to the table called "Total employment by industry". The 5 metropolitan areas with the highest total employment growth rates were (1) Las Vegas MSA (6.4\%), (2) Naples MSA in Florida (5.65\%), (3) Austin MSA in Texas (4.94\%), (4) McAllen MSA in Texas (4.92\%), and (5) Phoenix MSA in Arizona (4.86\%). The 5 metropolitan areas with the most serious decline in total employment were (1) Grand Forks between North Dakota and Minnesota (-0.47\%), (2) Muncie MSA in Indiana (-0.24\%), (3) Anniston MSA in Alabama (-0.21\%), (4) Florence MSA in Alabama (0.13\%), and (5) Rocky Mount MSA in North Carolina (-0.12\%).

There seems to be two types of jobs that the native-born are less likely to be engaged. The first type includes the jobs that tend to be dirty, dangerous, insecure, and dead-end (e.g. meat processing, construction labor, repair of oil tankers, kitchen chore) (Piore, 1979; Parrado and Kandel, 2008; Donato and Bankston, 2008). The other type includes the jobs that involve analytic skills but have limited prospects for transition to more prestigious managerial positions (e.g. computer programming, software testing). To the extent that the availability of such "immigrant jobs" in a particular locality is limited, and to the extent that immigrants tend to refer 
such jobs to their co-ethnics (Waldinger, 1996), the following place attribute may affect the new immigrants' destination choice behaviors.

Share of the Foreign-born by Co-ethnics: For a new immigrant of ethnic group k, the value of this place attribute for metropolitan area $\mathrm{j}$ is the proportion of the 1995 foreign-born population of metropolitan $\mathrm{j}$ belonging to ethnic $\mathrm{k}$. The coefficient of this variable is expected to be positive.

In light of the possibility that the destination choice behaviors of the new immigrants might be affected by the severity of winter, we specify the following climatic factor.

Coldness: For each metropolitan, this variable is defined as the average annual heating degreedays from 1951 to $1980 .{ }^{4}$ The unit is 1000 degree (F)-days.

Since the metropolitan areas are of very unequal sizes, it is important to control for the size of ecumene in our assessment of the roles of theoretically meaningful explanatory factors. For this purpose, we specify the following place attribute.

Ln(population size): For each metropolitan area as a potential destination of the 1995-2000 new immigrants, this place attribute is the natural $\log$ of a state's population size in 1995 , computed indirectly from the data of the 2000 census. The unit is $\ln (1,000,000$ persons). According to the data from BEA, the 5 most populous metropolitan areas were (1) New York CMSA (20.2 million), (2) Los Angeles CMSA (15.3 million), (3) Chicago CMSA (8.7 million), (4) Washington CMSA (7.2 million), and (5) San Francisco CMSA (6.6 million). The least populous among the 276 metropolitan areas was Naples MSA (slightly less than 0.2 million). The size of New York was 101 times the size of Naples.

4 Data source: US National Oceanic and Atmospheric Administration. For a few metropolitan areas where the data are missing, we estimate the values by interpolation from those of nearly metropolitan areas. 


\section{MULTIVARITE FINDINGS}

We split our input data into two parts by the country of birth and then apply the logit model to the two parts separately. Our reasons for doing so are the following. First, we have already found that the destination choice patterns differed greatly between the two countries of birth-- definitely much greater than among the five levels of educational attainment. Second, if we pool the input data of the two ethnic groups together, the number of interaction terms used to reflect the selective effects of the place attributes will become so large that it not only overwhelms the capacity of the computer but also makes the presentation of the estimated results unnecessarily messy. Third, because the sample size of the Mexican-born was as large as 4.3 times the sample size of the Indian-born, the application of the maximum likelihood method to the pooled data has a tendency to do a better job for explaining the destination choice pattern of the Mexican-born than for explaining the pattern of the Indian-born.

\subsection{Inferences from the estimated coefficients}

It turned out that the $\rho^{2}$ values of the best specifications of the model are as high as 0.3316 for those from Mexico and 0.3604 for those from India (Table 4). This finding suggests that in a statistical sense, our chosen explanatory variables have explained very well the destination choice patterns of both Mexican-born and Indian-born new immigrants, and that the explanation was somewhat better for the Indian-born. From the estimated coefficients of the explanatory variables and their associated t-ratios in the best specifications of the model, we make the following inferences. 


\begin{tabular}{|c|c|c|c|c|}
\hline \multirow{2}{*}{$\begin{array}{l}\text { Explanatory } \\
\text { Factor }\end{array}$} & \multicolumn{2}{|c|}{ Mexican-born } & \multicolumn{2}{|c|}{ Indian-born } \\
\hline & Coef. & t-ratio & Coef. & t-ratio \\
\hline \multicolumn{5}{|l|}{ 1. Attraction of Co-ethnic Communities } \\
\hline Ethnic Similarity & 0.323 & 51.6 & 0.577 & 35.8 \\
\hline Ethnic Similarity * Aged 40-49 & 0.065 & 9.2 & ---- & ---- \\
\hline Ethnic Similarity * Aged 50+ & 0.141 & 12.8 & 0.119 & 3.3 \\
\hline Ethnic Similarity * Less than High School & 0.065 & 14.4 & 0.369 & 11.0 \\
\hline Ethnic Similarity * Female & 0.127 & 30.1 & --- & --- \\
\hline \multicolumn{5}{|l|}{ 2. Effects of Labor Market Factors } \\
\hline Wage Level & 0.035 & 25.4 & 0.051 & 15.3 \\
\hline Total Employment Growth & 0.262 & 92.2 & 0.119 & 14.3 \\
\hline Job Increase in 1st Wage Decile * Less Than H. Sch. Graduation & 0.023 & 5.6 & ---- & ---- \\
\hline Job Increase in 2nd Wage Decile * At Most H. Sch. Graduation & ---- & ---- & 0.097 & 4.9 \\
\hline Job Increase in 3rd Wage Decile * High Sch. Grad. or Some College & 0.246 & 18.9 & --- & --- \\
\hline Job Increase in 8th Wage Decile * Some College or Bachelor's Degree & 0.171 & 10.1 & 0.083 & 5.1 \\
\hline Job Increase in 9th Wage Decile * At Least Bachelor's Degree & 0.222 & 12.0 & 0.123 & 11.1 \\
\hline Job Increase in 10th Wage Decile * At Least Bachelor's Degree & 0.037 & 4.1 & 0.240 & 42.0 \\
\hline \multicolumn{5}{|l|}{ 3. Strength of Co-ethnic Concentration among the Foreign-born } \\
\hline Share of the Foreign-born by Co-ethnics & 1.041 & 31.0 & 3.389 & 9.7 \\
\hline \multicolumn{5}{|l|}{ 4. Effect of Climate } \\
\hline Coldness * Aged $50+$ & ---- & ---- & -0.034 & -2.4 \\
\hline \multicolumn{5}{|l|}{ 5. Effect of Size of Ecumene } \\
\hline Ln(Population Size) & 0.977 & 239.9 & 0.917 & 90.1 \\
\hline p2 & \multicolumn{2}{|c|}{0.3316} & \multicolumn{2}{|c|}{0.3604} \\
\hline
\end{tabular}

The positive coefficients of Ethnic Similarity (0.323 in the Mexican model and 0.577 in the Indian model), together with the very large magnitudes of their associated t-ratios, indicate that both Mexican-born and Indian-born new immigrants were clearly subject to the attractions of their co-ethnic communities. The estimated coefficients of the interaction terms between Ethnic Similarity and the dummy variables representing the personal attributes of the new 
immigrants can be interpreted in the following way. First, the attraction by co-ethnic communities tended to be stronger at older ages. For those from Mexico, this attraction became stronger in the 40-49 age group and the strongest in the 50+ age group. For those from India, this attraction was not significantly different from age 20 to age 49 but became stronger in the $50+$ age group. Second, for both ethnic groups, those without a high school diploma were more subject to the attraction of co-ethnic communities than were their better educated counterparts. Third, for those from Mexico, females were more prone to being attracted by their co-ethnic communities than were their male counterparts.

An important technical point is that we can not safely infer from the fact that the estimated coefficient of Ethnic Similarity turned out to be much smaller for the Mexican-born (0.323) than for the Indian-born (0.577) that the former were much less subject to the attraction of co-ethnic communities than were the latter. The underlying reason for this risk of making a misleading inference is that the inter-metropolitan variation in the values of Ethnic Similarity is much greater for the Mexican-born than for the Indian-born, which is in turn due to the fact that the difference from the inter-metropolitan distribution of the total population in 1995 was much greater for the Mexican-born population than for the Indian-born population. A proper way to assess which of the two ethnic groups of new immigrants was more subject to the attraction of co-ethnic communities is to use the marginal contribution in $\rho^{2}$ obtained by the fixed-coefficient method. For similar reason, it is unsafe to make inference from the comparison of the estimated coefficients of 'Share of the Foreign-born by Co-ethnics' between the Mexican and Indian models. For all other place attributes such as wage level, the value assumed by any potential destination remains the same, irrespective of whether the new immigrants in question were from 
Mexico or from India. Consequently, for all other place attributes, it is safe to make the inference from comparing the corresponding coefficients between the Mexican and Indian models.

The estimated coefficients of labor market variables turned out to be quite sensible. Since the estimated coefficients of Wage Level are 0.035 in the Mexican model and 0.051 in the Indian model, we infer that both Mexican-born and Indian-born new immigrants were subject to the attraction of potential destinations with higher wages, and that the attraction was stronger for those from India than for those from Mexico. From the fact that the estimated coefficients of total employment growth are 0.262 and 0.119 in the two models, we infer that the new immigrants of both ethnic groups were more prone to being attracted to potential destinations with greater total employment growth, and that this attraction was much stronger for those from Mexico than for those from India.

With respect to the attraction of job increases in the bottom three wage deciles, the estimated coefficients in the Mexican model indicate that among the new immigrants from Mexico, those without a high school diploma were subject to the positive effect of the job increase in the lowest wage decile, whereas those with high school or some college education were subject to the positive effect of the job increase in the third wage decile. The estimated coefficient in the Indian model indicates that among the immigrants from India, those with at most high school education were subject to the positive effect of the job increase in the second wage decile.

With respect to the attraction of job increases in the top three wage deciles, the estimated coefficients indicate that the job increase in any of the top three wage deciles had a positive effect on the better educated immigrants from both Mexico and India, and that the positive effect 
of the job increase in the $10^{\text {th }}$ wage decile was much stronger on those from Indian than on those from Mexico.

With respect to the possibility of inter-ethnic competition among the foreign-born, the estimated coefficients of "Share of the Foreign-born by Co-ethnics" (1.041 in the Mexican model and 3.389 in the Indian model) suggest that the new immigrants of both ethnic groups tended to be attracted to the potential destinations where their co-ethnics represent a relatively large share of the foreign-born population. As mentioned previously, it is unsafe to infer from the relatively large coefficient in the Indian model that this effect was greater for those from India.

With respect to the effect of the climatic factor, we found that coldness of winter had no effect on the destination choices of the Mexican-born new immigrants, and that it had a negative effect on the Indian-born new immigrants who were in the $50+$ age group.

Finally, in light of the huge difference in population size among the metropolitan areas, it is natural that the estimated coefficients of $\operatorname{Ln}($ Population Size) turned out to be positive in both Mexican and Indian models. From a methodological point of view, it is extremely important to include this explanatory variable in the destination choice model, because its omission will grossly inflate the importance of the attractions of co-ethnic communities and higher wage level (see Appendix A). Being oblivious of this methodological issue, Zolberg (2001, p.10) and Light (2006, pp. 34-35) overstated the importance of the attraction by co-ethnic communities. ${ }^{5}$

\subsection{Assessment of the relative importance of explanatory factors}

Since some of the explanatory factors turned out to overlap substantially in explanatory powers, the fixed-coefficient method is much better than the maximizing method for assessing

\footnotetext{
${ }^{5}$ Light (2006, p. 34) stated that "new comers gravitate to settlement destinations in exact proportion to the prior settlement of co-ethnics in every destination."
} 
the relative importance of the explanatory factors. Based on the marginal contributions in $\rho^{2}$ computed from the fixed-coefficient method (Table 5), we make the following assessments.

\begin{tabular}{|c|c|c|}
\hline \multirow[b]{2}{*}{ Explanatory } & \multicolumn{2}{|c|}{ Marginal Contribution in $\mathrm{\rho 2}$} \\
\hline & New Immigrants & New Immigrants \\
\hline Factor & Born in Mexico & Born in India \\
\hline 1. Attraction of Co-ethnic Communities & 0.0366 & 0.0200 \\
\hline 2. Labor Market Factors & 0.0078 & 0.0179 \\
\hline Wage Level & 0.0021 & 0.0048 \\
\hline Total Employment Growth & 0.0067 & 0.0009 \\
\hline Expansion of Low Wage Jobs & 0.0003 & 0.0001 \\
\hline Expansion of High Wage Jobs & 0.0002 & 0.0074 \\
\hline 3. Strength of Co-ethnic Concentration among the Foreign-born & 0.0049 & 0.0005 \\
\hline 4. Climate (Coldness of Winter) & 0.0000 & 0.0000 \\
\hline 5. Size of Ecumene & 0.1717 & 0.1579 \\
\hline
\end{tabular}

Note: The marginal contributions in $\rho 2$ are computed by the fixed coefficient method.

For both Mexican-born and Indian-born new immigrants, the size of ecumene turned out to be the most important explanatory factor. This is simply due to that the metropolitan areas differ substantially in population size, and that ceteris paribus completely random choices by the immigrants will result in the tendency that bigger destinations get more immigrants. Thus, this finding is substantively uninteresting.

Among the substantively interesting explanatory factors used in our study, the attraction by co-ethnic communities turned out to be the most important for both Mexican-born and Indian- 
born new immigrants. Next in importance for both ethnic groups is the set of labor market factors.

It is worth highlighting that the attraction of co-ethnic communities was more powerful for those from Mexico than for those from India, whereas the influences of labor market factors were in general stronger for the Indian-born than for the Mexican-born.

Among the labor market factors, the attractions of (1) high wage level and (2) expansion of jobs in high wage deciles were more powerful for the Indian-born than for the Mexican-born. In contrast, the attractions of (1) high total employment growth and (2) expansion of jobs in low wage deciles were more powerful for the Mexican-born than for the Indian-born.

With respect to the possibility of interethnic competitions among the foreign-born, the explanatory power of the share of co-ethnics in foreign-born population was rather strong for the Mexican-born but quite modest for the Indian-born. Finally, the explanatory power of coldness was by far the weakest for both ethnic groups.

\subsection{Comparison between the predicted and observed destination choice patterns}

Since the values of $\rho^{2}$ for both Mexican and Indian models turned out to be much closer to 0 than to 1 , some readers may doubt our claim that our chosen explanatory factors have explained the destination choice patterns very well. To dispel this doubt, we now compare the predicted and observed destination choice proportions for the top 30 destinations for each ethnic group (Tables 6 and 7).

With respect to the most preferred destination, the share of the new Mexican immigrants by Los Angeles CMSA is observed to be $17.5 \%$ and predicted rather closely to be $18.4 \%$, whereas the share of the new Indian immigrants by New York CMSA is observed to be $18.5 \%$ and also predicted rather closely to be $19.6 \%$. 


\begin{tabular}{|c|c|c|c|c|c|c|}
\hline $\begin{array}{l}\text { Metropolitan } \\
\text { Area }\end{array}$ & $\begin{array}{r}\text { Observed } \\
\text { Rank }\end{array}$ & \multicolumn{2}{|c|}{ Number of Immigrants } & \multicolumn{3}{|c|}{$\%$ Share of Immigrants } \\
\hline Los Angeles-Riverside-Orange County & 1 & 191,136 & 200,576 & 17.49 & 18.36 & -0.86 \\
\hline Dallas-Fort Worth, TX CMSA & 2 & 85,031 & 70,154 & 7.78 & 6.42 & 1.36 \\
\hline Houston-Galveston-Brazoria, TX CMSA & 4 & 60,612 & 58,254 & 5.55 & 5.33 & 0.22 \\
\hline San Francisco-Oakland-San Jose & 5 & 57,745 & 66,982 & 5.29 & 6.13 & -0.85 \\
\hline Phoenix-Mesa, AZ MSA & 6 & 54,267 & 52,316 & 4.97 & 4.79 & 0.18 \\
\hline New York-Northern NJ-Long Island & 7 & 46,644 & 56,037 & 4.27 & 5.13 & -0.86 \\
\hline Atlanta, GA MSA & 8 & 39,092 & 20,329 & 3.58 & 1.86 & 1.72 \\
\hline San Diego, CA MSA & 10 & 23,870 & 37,447 & 2.18 & 3.43 & -1.24 \\
\hline Las Vegas, NV-AZ MSA & 11 & 19,585 & 25,978 & 1.79 & 2.38 & -0.59 \\
\hline Portland-Salem, OR-WA CMSA & 12 & 17,078 & 11,602 & 1.56 & 1.06 & 0.50 \\
\hline Austin-San Marcos, TX MSA & 13 & 17,047 & 16,734 & 1.56 & 1.53 & 0.03 \\
\hline Raleigh-Durham-Chapel Hill, NC MSA & 14 & 13,514 & 6,416 & 1.24 & 0.59 & 0.65 \\
\hline Charlotte-Gastonia-Rock Hill, NC-SC MSA & 15 & 12,033 & 5,476 & 1.10 & 0.50 & 0.60 \\
\hline EI Paso, TX MSA & 16 & 11,845 & 10,553 & 1.08 & 0.97 & 0.12 \\
\hline McAllen-Edinburg-Mission, TX MSA & 17 & 11,211 & 18,426 & 1.03 & 1.69 & -0.66 \\
\hline Salt Lake City-Ogden, UT MSA & 18 & 11,211 & 6,408 & 1.03 & 0.59 & 0.44 \\
\hline Greensboro--Winston-Salem--High Point & 19 & 10,607 & 3,995 & 0.97 & 0.37 & 0.61 \\
\hline Fresno, CA MSA & 20 & 10,592 & 8,680 & 0.97 & 0.79 & 0.18 \\
\hline Washington-Baltimore & 23 & 8,696 & 13,091 & 0.80 & 1.20 & -0.40 \\
\hline Salinas, CA MSA & 24 & 8,672 & 7,623 & 0.79 & 0.70 & 0.10 \\
\hline Minneapolis-St. Paul, MN-WI MSA & 25 & 8,116 & 5,829 & 0.74 & 0.53 & 0.21 \\
\hline Sacramento-Yolo, CA CMSA & 26 & 7,834 & 12,629 & 0.72 & 1.16 & -0.44 \\
\hline Philadelphia-Wilmington-Atlantic City & 27 & 7,380 & 8,618 & 0.68 & 0.79 & -0.11 \\
\hline Kansas City, MO-KS MSA & 28 & 7,059 & 4,857 & 0.65 & 0.44 & 0.20 \\
\hline Detroit-Ann Arbor-Flint, MI CMSA & 29 & 6,487 & 8,500 & 0.59 & 0.78 & -0.18 \\
\hline Miami-Fort Lauderdale, FL CMSA & 30 & 6,103 & 7,317 & 0.56 & 0.67 & -0.11 \\
\hline Sub-total of Top 30 Metros & & 881,508 & 859,479 & 80.68 & 78.67 & 2.02 \\
\hline All 276 Metros & & $1,092,543$ & $1,092,543$ & 100.00 & 100.00 & 0.00 \\
\hline
\end{tabular}

An important difference in destination choice behaviors between the two ethnic groups is that the second most preferred destination was a much more power attractor for those from Indian than for those from Mexico. This difference is very well reflected by the predicted results. The share of the new Mexican immigrants by Dallas CMSA (the second most preferred 
destination) is observed to be $7.8 \%$ and predicted as $6.4 \%$, whereas the share of the new Indian immigrants by San Francisco (the second most preferred destination) is observed to be $13.5 \%$ and predicted to be $12.6 \%$.

\begin{tabular}{|c|c|c|c|c|c|c|}
\hline \multirow{2}{*}{$\begin{array}{l}\text { Metropolitan } \\
\text { Area }\end{array}$} & \multirow{2}{*}{$\begin{array}{r}\text { Observed } \\
\text { Rank } \\
\end{array}$} & \multicolumn{2}{|c|}{ No. of Immigrants } & \multicolumn{3}{|c|}{$\%$ Share of Immigrants } \\
\hline & & Observed & Predicted & Observed & Predicted & Gap \\
\hline New York-Northern NJ-Long Island & 1 & 46,698 & 49,479 & 18.49 & 19.59 & -1.10 \\
\hline San Francisco-Oakland-San Jose & 2 & 34,117 & 31,790 & 13.51 & 12.59 & 0.92 \\
\hline Chicago-Gary-Kenosha & 3 & 16,859 & 15,456 & 6.68 & 6.12 & 0.56 \\
\hline Washington-Baltimore & 4 & 13,655 & 16,569 & 5.41 & 6.56 & -1.15 \\
\hline Los Angeles-Riverside-Orange County & 5 & 10,513 & 11,148 & 4.16 & 4.41 & -0.25 \\
\hline Boston-Worcester-Lawrence, MA-NH-ME-CT & 6 & 9,730 & 9,181 & 3.85 & 3.64 & 0.22 \\
\hline Dallas-Fort Worth, TX CMSA & 7 & 9,158 & 6,949 & 3.63 & 2.75 & 0.87 \\
\hline Detroit-Ann Arbor-Flint, MI CMSA & 8 & 8,978 & 7,756 & 3.56 & 3.07 & 0.48 \\
\hline Philadelphia-Wilmington-Atlantic City & 9 & 7,795 & 8,978 & 3.09 & 3.56 & -0.47 \\
\hline Houston-Galveston-Brazoria, TX CMSA & 10 & 5,985 & 6,510 & 2.37 & 2.58 & -0.21 \\
\hline Atlanta, GA MSA & 11 & 5,695 & 6,071 & 2.26 & 2.40 & -0.15 \\
\hline Seattle-Tacoma-Bremerton, WA CMSA & 12 & 3,846 & 3,329 & 1.52 & 1.32 & 0.20 \\
\hline Minneapolis-St. Paul, MN-WI MSA & 13 & 3,674 & 2,570 & 1.45 & 1.02 & 0.44 \\
\hline Columbus, $\mathrm{OH} \mathrm{MSA}$ & 14 & 2,891 & 1,669 & 1.14 & 0.66 & 0.48 \\
\hline Denver-Boulder-Greeley, CO CMSA & 15 & 2,530 & 1,716 & 1.00 & 0.68 & 0.32 \\
\hline Raleigh-Durham-Chapel Hill, NC MSA & 16 & 2,397 & 2,687 & 0.95 & 1.06 & -0.11 \\
\hline Phoenix-Mesa, AZ MSA & 17 & 2,374 & 2,045 & 0.94 & 0.81 & 0.13 \\
\hline Cleveland-Akron, OH CMSA & 18 & 2,319 & 2,100 & 0.92 & 0.83 & 0.09 \\
\hline Pittsburgh, PA MSA & 19 & 2,209 & 1,700 & 0.87 & 0.67 & 0.20 \\
\hline Sacramento-Yolo, CA CMSA & 20 & 2,060 & 2,389 & 0.82 & 0.95 & -0.13 \\
\hline Austin-San Marcos, TX MSA & 21 & 2,053 & 3,047 & 0.81 & 1.21 & -0.39 \\
\hline Portland-Salem, OR-WA CMSA & 22 & 2,013 & 1,426 & 0.80 & 0.56 & 0.23 \\
\hline Miami-Fort Lauderdale, FL CMSA & 23 & 1,888 & 1,919 & 0.75 & 0.76 & -0.01 \\
\hline Cincinnati-Hamilton, OH-KY-IN CMSA & 24 & 1,817 & 1,778 & 0.72 & 0.70 & 0.02 \\
\hline Kansas City, MO-KS MSA & 25 & 1,622 & 1,199 & 0.64 & 0.47 & 0.17 \\
\hline San Diego, CA MSA & 26 & 1,520 & 1,739 & 0.60 & 0.69 & -0.09 \\
\hline St. Louis, MO-IL MSA & 27 & 1,426 & 1,535 & 0.56 & 0.61 & -0.04 \\
\hline Tampa-St. Petersburg-Clearwater, FL MSA & 28 & 1,379 & 1,669 & 0.55 & 0.66 & -0.11 \\
\hline Milwaukee-Racine, WI CMSA & 29 & 1,379 & 1,034 & 0.55 & 0.41 & 0.14 \\
\hline Hartford, CT NECMA & 30 & 1,300 & 1,371 & 0.51 & 0.54 & -0.03 \\
\hline Sub-total of Top 30 Metros & & 209,880 & 206,809 & 83.11 & 81.89 & 1.22 \\
\hline All 276 Metros & & 252,544 & 252,544 & 100.00 & 100.00 & 0.00 \\
\hline
\end{tabular}

In general, the predicted and observed destination choice patterns are quite similar. The Pearson's correlation coefficient between the predicted and observed sets destination choice proportions across all 276 destinations is as high as 0.986 for the Mexican-born and 0.995 for the 
Indian-born. The somewhat poorer prediction for the Mexican-born involved the underprediction of the shares by Atlanta MSA, Raleigh MSA, Charlotte MSA, and Greensboro MSA (Table 6). These are the so-called "new destinations" in a region where employers were actively recruiting low-skilled Hispanic, especially Mexican, immigrants in the 1990s (Johnson-Webb, 2003; Hernandez-Leon and Zuniga, 2000). This information from the residuals suggests the usefulness of introducing an explanatory variable that can represent the inter-metropolitan variation in the intensity of recruitment by employers.

\section{CONCLUDING DISCUSSION}

We have found several similarities in destination choice patterns between the Mexicanborn and Indian-born immigrants who arrived in the late 1990s and went to the set of 276 metropolitan areas. First, both were highly concentrated in a handful of large metropolitan areas: more than $50 \%$ went to the top 7 destinations. Second, they shared rather strong preferences for the west coast. Third, both were important contributors to the "new destinations" in the South Atlantic Division. Fourth, both showed a tendency that the better educated had a more dispersed destination choice pattern.

We have also found major differences in destination choice patterns between these two ethnic groups. First, Los Angeles CMSA on the west coast was by far the most favorite destination for the Mexican-born, whereas New York CMSA on the east coast was by far the most attractive destination for the Indian-born. This contrast was the sharpest at the lowest level of educational attainment and became somewhat muted at higher levels of educational attainment. Second, with respect to the second most powerful attractor of each of these two ethnic groups, San Francisco CMSA's attraction of the Indian-born (13.5\%) was much greater than Dallas 
CMSA's attraction of the Mexican-born (7.8\%). Third, with respect to the metropolitan areas that were in the set of the top 30 destinations for one ethnic group but not in the set of top 30 destinations of the other ethnic group, there was a clear spatial pattern: most of those for the Mexican-born were located in the western part of the US, whereas those for the Indian-born were all located in the eastern part of the US.

Our multivariate analysis has revealed that the destination choice behaviors of both ethnic groups were in general consistent with the major theories of migration (Portes, 1995; Massey et al, 1993; Piore, 1979; Sassen, 1988 and 1991; Waldinger, 1996). Both groups were subject to (1) the attraction of co-ethnic communities and (2) the positive influences of wage level and total employment growth. With respect to the job increases in different wage deciles, both ethnic groups share the pattern that the less educated were subject to the pull of increases in low-wage jobs, whereas the better educated were subject to the pull of increases in high-wage jobs. With respect to the possibility of competitions against other foreign-born ethnics, both ethnic groups were found to be more prone to selecting destinations where their co-ethnics represented a relatively high proportion of the foreign-born population.

Our multivariate analysis has also shown that the relative explanatory powers of our chosen explanatory factors differed substantially between the two ethnic groups. The Mexicanborn were more subject to the attractions of (1) larger co-ethnic communities, (2) greater overall employment growth, (3) more job increases in low wage deciles, and (4) greater share of the foreign-born population by co-ethnics. In contrast, the Indian-born were more attracted by (1) higher wage level, and (2) more job increases in high wage deciles.

The observed sharp differences in the spatial patterns of the destination choices of these two groups of new immigrants depended partly on the fact that the foreign-born stocks of these 
two ethnic groups were very differently distributed in 1995, and that the new immigrants of both ethnic groups were still rather strongly attracted by their co-ethnic communities, although the findings of Liaw and Frey (2007) in their state-based study suggest strongly that this attraction became weaker in the late 1990s than in the late 1980s. We have also found that these observed differences depended partly on the fact that the major explanatory factors had rather different effects on the new immigrants of these two ethnic groups. Of particular interest in our multivariate findings is the very strong attraction of the best educated from India by the job increase in the highest wage decile, which was vividly reflected by the fact that as the second most preferred destination, the attraction of San Francisco CMSA (which includes the Silicon Valley) for those from India was much stronger than the attraction of Dallas CMSA for those from Mexico.

Based on the above findings as well as the findings of Liaw and Frey (2007) regarding the changes in the choices of destination states by the newly-arrived immigrants from the late 1980s to the late 1990s, we anticipate that the main contributions of our work on the changes in the destination choice patterns of metropolitan-bound new immigrants from 1985-1990 to 19952000 will be (1) the revelation of how and why the relative explanatory powers of substantively meaningful explanatory factors help account for the ethnically-selective dispersals of the newlyarrived immigrants among the metropolitan areas from the late 1980s to the late 1990s, and (2) the assessment of how industrial shifts and evolving labor practices can help account for immigrant dispersal in not only the US but also other countries like Canada where the dispersal has started to emerge since the beginning of the $21^{\text {st }}$ century without a major change in immigration regulation like IRCA or the strengthening of border control. ${ }^{6}$

\footnotetext{
${ }^{6}$ We used the data of the 2006 Canadian census to compare the distributions of four groups of immigrants (those landed before 1991, those landed in 1991-1995, those landed in 1996-2000, and those landed in 2001-2006) against
} 


\section{APPENDIX A \\ Advantages of Using both Maximizing and Fixed-Coefficient Methods in Assessing the Relative Importance of Explanatory Factors}

In attempting to explain a dependent variable by a set of explanatory factors, empirical researchers commonly encounter the fact that some of the substantively meaningful explanatory factors overlap in explanatory powers. This inherent property of many real-world systems makes it difficult for researchers to assess the relative importance of various subsets of explanatory variables. There have been two relatively unsatisfactory ways to deal with this problem. One way is to create principle components from the substantively meaningful explanatory variables and then use the principal components as composite explanatory variables in a multivariate model to explain the dependent variable, as demonstrated by Leach and Bean (2008). This has the technical advantage of removing the overlaps in explanatory powers but a serious shortcoming of the vagueness in the substantive meanings of the estimated coefficients. The other way is to remove some of the substantively meaningful factors that overlap in explanatory powers. ${ }^{7}$ To the extent that the removed explanatory factors have inherent effects on the dependent variable, this way has the undesirable consequence that the estimated result will artificially inflate the coefficients of the remaining explanatory factors. Both of these ways are equivalent to cutting the feet to fit the shoes.

A better approach is to use what we have defined in the text as the maximizing and fixedcoefficient methods to achieve a better understanding of real-world systems that are inherently

the distribution of the Canadian-born among the 33 metropolitan areas. We found that the Gini ratio (an indicator of relative concentration) increased from 0.361 for the first group to 0.468 for the second group and 0.472 for the third group but then decreased sharply to 0.426 for the most recent group.

7 It is important to realize that "overlap in explanatory power" and "multicollinearity" are different concepts. Otomo and Liaw (2003) provide a real-world example that shows (1) that two highly correlated explanatory variables do not overlap in explanatory powers, (2) that the two highly correlated explanatory variables actually strengthen each other's explanatory power in the same model, and (3) that the removal of one of the correlated explanatory variables causes the estimated coefficient of the remaining explanatory variable substantively absurd. 
complex. The maximizing method is helpful in revealing how various explanatory factors overlap in explanatory powers, whereas the fixed-coefficient method can help avoid unintentionally understating the separate explanatory powers of the explanatory factors that overlap in explanatory powers. Our main point is that when we encounter complexity in the real-world, we should make our best effort to understand it rather than artificially removing it.

In the rest of this appendix, we demonstrate the usefulness of these two methods with our data on the destination choices made by the Mexican-born. Using both methods, we delete several explanatory factors from the best specification of the model and show how the value of $\rho^{2}$ is affected. The estimated coefficients in the partial models after the selective deletions are the ones generated by the maximizing method (Appendix Tables 1(A) and 1(B)).

In column (2) of Appendix Table 1(A), we find that when Ethnic Similarity and its interaction with personal attributes of the new immigrants are deleted, the estimated coefficient of "Share of the Foreign-born by Co-ethnics" increases sharply from 1.041 to 3.550 . We also find in column (3) of this table that when "Share of the Foreign-born by Co-ethnics" is deleted, the estimated coefficient of Ethnic Similarity jumps from 0.323 to 0.466 . These two findings indicate clearly that the explanatory power of Ethnic Similarity overlaps substantially with the explanatory power of "Share of the Foreign-born by Co-ethnics".

Due to the substantial overlap in explanatory powers between the Ethnic Similarity and "Share of the Foreign-born by Co-ethnics", the marginal contribution in $\rho^{2}$ (MCR) generated by the maximizing method for each of these two factors $(0.0054$ for the former and 0.0006 for the latter) seriously understates their respective explanatory powers. In contrast, by not allowing these two factors to take away each other's explanatory power, the fixed-coefficient method reveals the fact that these two explanatory factors are actually quite important by yielding much greater values of MCR (0.0366 and 0.0050$)$. 


\begin{tabular}{|c|c|c|c|c|c|c|c|c|}
\hline \multirow[t]{2}{*}{ Explanatory Factor } & \multicolumn{2}{|c|}{$\begin{array}{c}(1) \\
\text { Best } \\
\text { Specification } \\
\end{array}$} & \multicolumn{2}{|c|}{$\begin{array}{c}(2) \\
\text { - Ethnic } \\
\text { Similarity } \\
\end{array}$} & \multicolumn{2}{|c|}{$\begin{array}{c}\text { (3) } \\
\text { - Competition } \\
\text { with other } \\
\text { Foreign-born } \\
\end{array}$} & \multicolumn{2}{|c|}{$\begin{array}{c}(4) \\
\text { - Ethnic } \\
\text { Similarity \& } \\
\text { Competition }\end{array}$} \\
\hline & Coef. & $\begin{array}{r}\mathrm{t}- \\
\text { ratio }\end{array}$ & Coef. & $\begin{array}{r}\mathrm{t}- \\
\text { ratio }\end{array}$ & Coef. & $\begin{array}{r}\mathrm{t}- \\
\text { ratio }\end{array}$ & Coef. & $\begin{array}{r}\mathrm{t}- \\
\text { ratio }\end{array}$ \\
\hline \multicolumn{9}{|l|}{ 1. Attraction of Co-ethnic Communities } \\
\hline Ethnic Similarity & 0.323 & 51.6 & --- & ---- & 0.466 & 108.0 & --- & --- \\
\hline Ethnic Similarity * Aged 40-49 & 0.065 & 9.2 & --- & --- & 0.066 & 9.3 & --- & --- \\
\hline Ethnic Similarity * Aged $50+$ & 0.141 & 12.8 & --- & --- & 0.143 & 12.9 & --- & ---- \\
\hline Ethnic Similarity * Less than High School & 0.065 & 14.4 & --- & --- & 0.060 & 13.2 & --- & --- \\
\hline \multicolumn{9}{|l|}{ 2. Effects of Labor Market Factors } \\
\hline Wage Level & 0.035 & 25.4 & 0.054 & 38.0 & 0.017 & 13.7 & 0.119 & -97.1 \\
\hline Total Employment Growth & 0.262 & 92.2 & 0.297 & 105.6 & 0.256 & 90.5 & 0.498 & 192.7 \\
\hline $\begin{array}{l}\text { Job Increase in 1st Wage Decile * Less Than H. Sch. Graduation } \\
\text { Job Increase in 3rd Wage Decile * High Sch. Grad. or }\end{array}$ & 0.023 & 5.6 & 0.074 & 18.0 & 0.001 & 0.3 & 0.068 & -16.4 \\
\hline Some College & 0.246 & 18.9 & 0.210 & 16.2 & 0.266 & 20.6 & 0.035 & 2.8 \\
\hline Job Increase in 8th Wage Decile * Some College or Bachelor's Degree & 0.171 & 10.1 & 0.126 & 7.3 & 0.192 & 11.4 & 0.022 & -1.3 \\
\hline Job Increase in 9th Wage Decile * At Least Bachelor's Degree & 0.222 & 12.0 & 0.162 & 8.8 & 0.239 & 13.0 & 0.098 & -5.4 \\
\hline $\begin{array}{l}\text { Job Increase in 10th Wage Decile * At Least Bachelor's Degree } \\
\text { 3. Competition with Other Foreign-born }\end{array}$ & 0.037 & 4.1 & 0.043 & 4.5 & 0.038 & 4.3 & 0.046 & 4.5 \\
\hline $\begin{array}{l}\text { Share of the Foreign-born by Co-ethnics } \\
\text { 4. Effect of Size of Ecumene }\end{array}$ & 1.041 & 31.0 & 3.550 & 226.5 & ---- & --- & --- & --- \\
\hline Ln(Population Size) & 0.977 & 239.9 & 1.115 & 283.5 & 0.957 & 240.2 & 1.535 & 386.3 \\
\hline \multicolumn{9}{|l|}{ Maximizing Method: } \\
\hline Rho-square & \multicolumn{2}{|c|}{0.3316} & \multicolumn{2}{|c|}{0.3262} & \multicolumn{2}{|c|}{0.3310} & \multicolumn{2}{|c|}{0.2905} \\
\hline Marginal Contribution in Rho-square & \multicolumn{2}{|c|}{---- } & \multicolumn{2}{|c|}{0.0054} & \multicolumn{2}{|c|}{0.0006} & \multicolumn{2}{|c|}{0.0411} \\
\hline \multicolumn{9}{|l|}{ Fixed Coefficient Method: } \\
\hline Rho-square & \multicolumn{2}{|c|}{0.3316} & \multicolumn{2}{|c|}{0.2950} & \multicolumn{2}{|c|}{0.3266} & \multicolumn{2}{|c|}{0.2658} \\
\hline Marginal Contribution in Rho-square & \multicolumn{2}{|c|}{---- } & \multicolumn{2}{|c|}{0.0366} & \multicolumn{2}{|c|}{0.0050} & \multicolumn{2}{|c|}{0.0658} \\
\hline
\end{tabular}

Note: The choice set includes 276 largest moetropolitan areas as potential destinations.

When both of these two factors are deleted (see column (4) of this table), the estimated coefficient of $\operatorname{Ln}$ (Population Size) jumps from 0.977 to 1.535 , implying that the explanatory powers of these two factors also overlap substantially with that of $\operatorname{Ln}($ Population Size). This additional overlap in explanatory powers also causes the maximizing method to understate substantially the joint explanatory power of these two factors. It generates a MCR value of 0.0411 , compared with 0.0658 which is generated by the fixed-coefficient method.

What is more interesting in column (4) is that the removal of these two factors causes the coefficient of Wage Level to assume a substantively nonsensical negative sign, which is indicated to be highly trustworthy by the huge magnitude of the associated t-ratio (-97.1). This 
perverse finding results from the fact that the metropolitan areas where Mexican-born residents represented a high proportion of the total or foreign-born population were mostly places with relatively low wage levels, and the fact that the Mexican-born new immigrants had a rather strong tendency to be close to their co-ethnics even in the late 1990s. Here we see a clear example of a substantively absurd finding about a labor market factor, resulting from the removal of (or the failure to include) highly correlated explanatory factors. Actually, column (4) also shows that the removal of these two explanatory factors causes the coefficients of three other labor market variables to become substantively nonsensical.

Column (2) of Appendix Table 1(B) shows that the removal of the theoretically uninteresting Ln(Population Size) results in a substantial inflation of the coefficient of Ethnic Similarity from 0.323 to 0.713 as well as a huge magnification of the coefficient of Wage Level from 0.035 to 0.267 . In other words, the failure to consider the huge explanatory power of population size forces the research to seriously over-state the importance of the attractions of metropolitan areas with larger co-ethnic communities and higher wage levels. This column also shows that the failure to control for the effect of population size results in a substantively nonsensical finding that the best educated Mexican immigrants had a strong tendency to avoid destinations with better job opportunities in the highest wage decile. 


\begin{tabular}{|c|c|c|c|c|c|c|}
\hline \multirow[t]{2}{*}{ Explanatory Factor } & \multicolumn{2}{|c|}{$\begin{array}{c}\text { (1) } \\
\text { Best } \\
\text { Specification }\end{array}$} & \multicolumn{2}{|c|}{$\begin{array}{c}(2) \\
- \text { Ecumene } \\
\text { Size }\end{array}$} & \multicolumn{2}{|c|}{$\begin{array}{c}(3) \\
\text { - Labor Market } \\
\text { Factors }\end{array}$} \\
\hline & Coef. & $\begin{array}{r}\mathrm{t}- \\
\text { ratio }\end{array}$ & Coef. & $\begin{array}{r}\mathrm{t}- \\
\text { ratio }\end{array}$ & Coef. & t-ratio \\
\hline \multicolumn{7}{|l|}{ 1. Attraction of Co-ethnic Communities } \\
\hline Ethnic Similarity & 0.323 & 51.6 & 0.713 & 113.3 & 0.386 & 65.8 \\
\hline Ethnic Similarity * Aged 40-49 & 0.065 & 9.2 & 0.081 & 10.2 & 0.058 & 8.7 \\
\hline Ethnic Similarity * Aged 50+ & 0.141 & 12.8 & 0.179 & 14.3 & 0.127 & 12.2 \\
\hline Ethnic Similarity * Less than High School & 0.065 & 14.4 & 0.110 & 22.3 & 0.086 & 21.4 \\
\hline Ethnic Similarity * Female & 0.127 & 30.1 & 0.152 & 32.5 & 0.116 & 29.4 \\
\hline \multicolumn{7}{|l|}{ 2. Effects of Labor Market Factors } \\
\hline Wage Level & 0.035 & 25.4 & 0.267 & 274.2 & 0.037 & 27.5 \\
\hline Total Employment Growth & 0.262 & 92.2 & 0.258 & 96.7 & --- & --- \\
\hline Job Increase in 1st Wage Decile * Less Than H. Sch. Graduation & 0.023 & 5.6 & 0.094 & 23.1 & --- & --- \\
\hline Job Increase in 3rd Wage Decile * High Sch. Grad. or Some College & 0.246 & 18.9 & 0.128 & 11.5 & ---- & --- \\
\hline Job Increase in 8th Wage Decile * Some College or Bachelor's Degree & 0.171 & 10.1 & 0.099 & 6.9 & ---- & ---- \\
\hline Job Increase in 9th Wage Decile * At Least Bachelor's Degree & 0.222 & 12.0 & 0.095 & 6.5 & ---- & --- \\
\hline \multicolumn{7}{|l|}{ 3. Competition with Other Foreign-born } \\
\hline Share of the Foreign-born by Co-ethnics & 1.041 & 31.0 & 0.169 & -5.3 & 0.654 & 20.9 \\
\hline \multicolumn{7}{|l|}{ 4. Effect of Size of Ecumene } \\
\hline Ln(Population Size) & 0.977 & 239.9 & ---- & ---- & 1.009 & 345.8 \\
\hline \multicolumn{7}{|l|}{ Maximizing Method: } \\
\hline Rho-square & \multicolumn{2}{|c|}{0.3316} & \multicolumn{2}{|c|}{0.2873} & \multicolumn{2}{|c|}{0.3248} \\
\hline Marginal Contribution in Rho-square & \multicolumn{2}{|c|}{----} & \multicolumn{2}{|c|}{0.0443} & \multicolumn{2}{|c|}{0.0068} \\
\hline \multicolumn{7}{|l|}{ Fixed Coefficient Method: } \\
\hline Rho-square & \multicolumn{2}{|c|}{0.3316} & \multicolumn{2}{|c|}{0.1599} & \multicolumn{2}{|c|}{0.3238} \\
\hline Marginal Contribution in Rho-square & \multicolumn{2}{|c|}{---- } & \multicolumn{2}{|c|}{0.1717} & \multicolumn{2}{|c|}{0.0078} \\
\hline
\end{tabular}

Finally, column (3) of Appendix Table 1(B) shows that the explanatory power of the set of Labor Market Factors does not overlap very strongly with those of the remaining explanatory factors so that its values of MCR do not differ greatly between the two methods of assessment. The key point here is that when we compare columns (1) and (6), we see that the maximizing method implies that the explanatory power of Ethnic Similarity was somewhat weaker than that of Labor Market Factors (0.0054 versus 0.0068), whereas the fixed-coefficient method implies that the explanatory power of Ethnic Similarity was much greater than that of Labor Market 
Factors (0.0366 versus 0.0078$)$. Clearly, the comparison based on the maximizing method is very misleading.

In sum, we have demonstrated the usefulness of using the maximizing and fixedcoefficient methods to get a better understanding of a complex real-world process in which substantial overlaps in explanatory powers among the explanatory factors exist. We hope that our demonstration can help other researchers become better users of multivariate statistical models.

\section{REFERENCES}

Bean, F. D., Leach. M., and Lowell, B. L. (2004) “Immigrant Job Quality and Mobility in the United States," Work and Occupation 31: 499-518.

Donato, K. M. and Bankston, C. L. III. (2008) “The Origins of Employer Demand for Immigrants in a New Destination: The Salience of Soft Skills in a Volatile Economy," in Massey, D. S. (ed.) New Faces in New Places: The Chanaging Geography of American Immigration, pp. 99-123. New York: Russell Sage Foundation.

Frey, W. H. and Liaw, K.-L. (2005) "Migration within the United States: Role of Race and Ethnicity, " pp.207-262 in Gary Burtless and Janet Rothenberg Pack (eds) BrookingsWharton Papers on Urban Affairs, 2005. Washington DC: The Brookings Institution Press.

Gozdziak, E. M. and Bump, M. N. (2004) "Poultry, Apples, and New Immigrants in the Rural Communities of the Shenandoah Valley: An Ethnographic Case Study," International Migration 42(1): 149-164. 
Grey, M. A. and Woodrick, A. C. (2002) "Unofficial Sister Cities: Meatpacking Labor Migration Between Villachuato, Mexico, and Marshalltown, Iowa," Human Organization 61(4): 364-376.

Hernandez-Leon, R., and Zuniga, V. (2000) "Making Carpet by the Mile: The Emergence of a Mexican Immigrant Community in an Industrial Region of the U.S. Historical South," Social Science Quarterly 81(1): 49-66.

Johnson-Webb, K. D. (2003) Recruiting Hispanic Labor: Immigrants in Non-Traditional Areas. New York: LFB Scholarly Publishing LLC.

Kandel, E. W. and Parrado, E. A. (2005) "Restructuring of the US Meat Processing Industryand New Hispanic MigrantDestinations," Population and Development Review 31(3): 447471.

Kochhar, R. (2006) "Growth in the Foreign-Born Workforce and Employment of the Native Born,” Report, Pew Hispanic Center. www.pewhispanic.org, last access on February 10, 2007.

Leach, M. A. and Bean, F. D. (2008) "The Structure and Dynamics of Mexican Migration to New Destinations in the United States," in Massey, D. S. (ed.) New Faces in New Places: The Chanaging Geography of American Immigration, pp. 99-123. New York: Russell Sage Foundation.

Liaw, K.-L. and Frey, W. H.. (1996) 'Interstate Migration of Young American Adults in 198590: An Explanation Using a Nested Logit Model.” Geographical Systems 3: 301-334.

Liaw, K.-L. and Frey, W. H. (1998) "Destination Choices of 1985-90 Young Immigrants to the United States: Importance of Race, Education Attainment, and Labor Force," International Journal of Population Geography 4: 49-61. 
Liaw, K. L. and Frey, W. H. (2007) “Multivariate Explanation of the 1985-1990 and 1995-2000 Destination Choices of Newly Arrived Immigrants in the United States: The Beginning of a New Trend?" Population, Space and Place 13: 377-399.

Liaw, K.-L. and Ishikawa, Y. (2008) "Destination Choice of the 1995-2000 Immigrants to Japan: Salient Features and Multivariate Explanation," Environment and Planning A 40: 806-830. Light, I. (2006) Deflecting Immgration: Networks, Markets, and Regulation in Los Angeles. New York: Russell Sage Foundation.

Massey, D. S. (ed.) (2008) New Faces in New Places: The Chanaging Geography of American Immigration. New York: Russell Sage Foundation.

Massey D S, Arango J, Hugo G, Kouaouci A, Pellegrino A, Taylor J E, 1993, "Theories of international migration: a review and appraisal" Population and Development Review 19 $431-468$

McFadden, D. (1974) “Conditional Logit Analysis of Qualitative Choice Behavior.” In Frontiers in Econometrics, edited by P. Zarembka. New York: Academic Press, pp. 105-142.

Otomo, A. and Liaw, K.-L. (2003) “An Invitation to Multivariate Analysis: An Example About the Effect of Educational Attainment on Migration Propensities in Japan," SEDAP Research Paper, No. 113, SEDAP Research Program, McMaster University, Hamilton, Ontario, L8S 4M4, Canada.

Parrado, E. A. and Kandel, W. (2008) "New Hispanic Migrant Destinations: A Tale of Two Industries," in Massey, D. S. (ed.) New Faces in New Places: The Chanaging Geography of American Immigration, pp. 99-123. New York: Russell Sage Foundation. 
Passel, J. S. and Zimmermann, W. (2001) “Are Immigrants Leaving California? Settlement Patterns of Immigrants in the Late 1990s," Research Report, Pub. ID\#410287, The Urban Institute, Washington, D.C.

Passsel, J. S. and Suro, R. (2005) Rise, Peak, and Decline: Trends in U. S. Immigration, 19922004. Pew Hispanic Center, Washington, D.C.(www.pewhsipanic.org)

Piore, M. P. (1979) Birds of Passage: Migrant Labor and Industrial Societies. Cambridge University Press.

Portes, A. (ed) (1995) The Economic Sociology of Immigration, New York: Russell Sage Foundation.

Sassen, S. (1988) The Mobility of Labor and Capital, Cambridge: Cambridge University Press.

Sassen, S. (1991) The Global City: New York, London, Tokyo. Princeton, NJ: Princeton University Press.

Singer, A., S. W. Hardwick and C. B. Brettell (eds) (2008) Twenty-First Century Gateways: Immigration Incorporation in Suburban America. Washington DC: The Brookings Institution.

Waldinger, R. (1996) Still the Promised City? African Americans and New Immigrants in Industrial New York. Cambridge, Massachusetts: Harvard University Press.

Waters, M. C. and Jiménez, T. R. (2005) “Assessing Immigrant Assimilation: New Empirical and Theoretical Challenges," Annual Review of Sociology 31: 105-125.

Wright, E. K. and Dwyer, R. E. (2003) “The patterns of job expansions in the USA: a comparison of the 1960s and 1990s," Socio-Economic Review 1: 289-325. 
Xu, L. and Liaw, K.-L. (2006) "Initial Destination Choices of Skilled-worker Immigrants from South Asia to Canada: Assessment of the Relative Importance of Explanatory Factors," Canadian Journal of Regional Science, forthcoming.

Zolberg, A. R. (2001) "Introduction: Beyond the Crisis," in Global Migrants, Global Refugees: Problems and Solutions, edited by A. R. Zolberg and P. M. Benda. New York: Berghan Books. 